\title{
BK Polyomavirus Nephropathy in Kidney Transplantation: Balancing Rejection and Infection
}

\author{
Chia-Lin Shen ${ }^{1,2,3}{ }^{(}$, Bo-Sheng $W_{u}{ }^{3,4}$, Tse-Jen Lien ${ }^{1,3,5}$, An-Hang Yang ${ }^{3,4,6}$ and Chih-Yu Yang ${ }^{1,3,4,7,8, *(\mathbb{D})}$ \\ 1 Division of Nephrology, Department of Medicine, Taipei Veterans General Hospital, Taipei 11217, Taiwan; \\ annieshen1982@gmail.com (C.-L.S.); jenmei2005@gmail.com (T.-J.L.) \\ 2 Jen Chia Clinic, New Taipei City 24147, Taiwan \\ 3 School of Medicine, Faculty of Medicine, National Yang Ming Chiao Tung University, Taipei 11221, Taiwan; \\ boshengw16507@gm.ym.edu.tw (B.-S.W.); ahyang@vghtpe.gov.tw (A.-H.Y.) \\ 4 School of Medicine, Institute of Clinical Medicine, National Yang Ming Chiao Tung University, \\ Taipei 11221, Taiwan \\ 5 Jen Mei Clinic, New Taipei City 24759, Taiwan \\ 6 Department of Pathology, Taipei Veteran General Hospital, Taipei 11217, Taiwan \\ 7 Stem Cell Research Center, National Yang Ming Chiao Tung University, Taipei 11221, Taiwan \\ 8 Center for Intelligent Drug Systems and Smart Bio-Devices (IDS2B), Hsinchu 30010, Taiwan \\ * Correspondence: cyyang3@vghtpe.gov.tw
}

check for

updates

Citation: Shen, C.-L.; Wu, B.-S.; Lien, T.-J.; Yang, A.-H.; Yang, C.-Y. BK Polyomavirus Nephropathy in Kidney Transplantation: Balancing Rejection and Infection. Viruses 2021, 13, 487. https://doi.org/10.3390/v13030487

Academic Editor: Valeria Pietropaolo

Received: 31 January 2021

Accepted: 14 March 2021

Published: 16 March 2021

Publisher's Note: MDPI stays neutral with regard to jurisdictional claims in published maps and institutional affiliations.

Copyright: (c) 2021 by the authors. Licensee MDPI, Basel, Switzerland. This article is an open access article distributed under the terms and conditions of the Creative Commons Attribution (CC BY) license (https:/ / creativecommons.org/licenses/by/ $4.0 /)$.

\begin{abstract}
BK polyomavirus nephropathy (BKVN) and allograft rejection are two closely-associated diseases on opposite ends of the immune scale in kidney transplant recipients. The principle of balancing the immune system remains the mainstay of therapeutic strategy. While patient outcomes can be improved through screening, risk factors identification, and rapid reduction of immunosuppressants, a lack of standard curative therapy is the primary concern during clinical practice. Additionally, difficulty in pathological differential diagnosis and clinicopathology's dissociation pose problems for a definite diagnosis. This article discusses the delicate evaluation needed to optimize immunosuppression and reviews recent advances in molecular diagnosis and immunological therapy for BKVN patients. New biomarkers for BKVN diagnosis are under development. For example, measurement of virus-specific $\mathrm{T}$ cell level may play a role in steering immunosuppressants. The development of cellular therapy may provide prevention, even a cure, for BKVN, a complex post-transplant complication.
\end{abstract}

Keywords: BK polyomavirus nephropathy; kidney transplant; acute rejection; immunosuppressants; tacrolimus

\section{Introduction}

BK polyomavirus nephropathy $(\mathrm{BKVN})$ and allograft rejection are two significant post-transplant complications on opposite ends of the immune spectrum (Figure 1). Parajuli et al. studied 3-year outcomes between these two diseases retrospectively. While BKVN and rejection are both prominent causes of kidney damage, renal function 3 years after diagnosis was worse for BKVN than for rejection [1]. The leading cause of BKVN is over-immunosuppression that reactivated the latent BK polyomavirus (BKPyV) within the recipient or reinforced $\mathrm{BKPyV}$ infection inside the allograft. No effective direct antiviral therapy is currently available; thus, since the first case was identified in 1971, immunosuppressant (IS) reduction remains the primary strategy for BKVN [2]. On the other hand, insufficient IS usage predisposes acute or chronic rejection, leading to graft function decline or graft loss as well.

Early diagnosis based on onset time and clinical manifestation is difficult due to similar clinical presentation of graft rejection and BKVN. Therefore, the highest principle in clinical practice is keeping a balance between rejection and infection [3]. This article discusses the evaluations needed for optimal immunosuppression to avoid infection or reactivation 
of the BKPyV in kidney transplant recipients (KTRs). In the case of confirmed BKPyV infection, control of the disease progression to preserve the graft function is also reviewed.

\section{Balanced immune system}

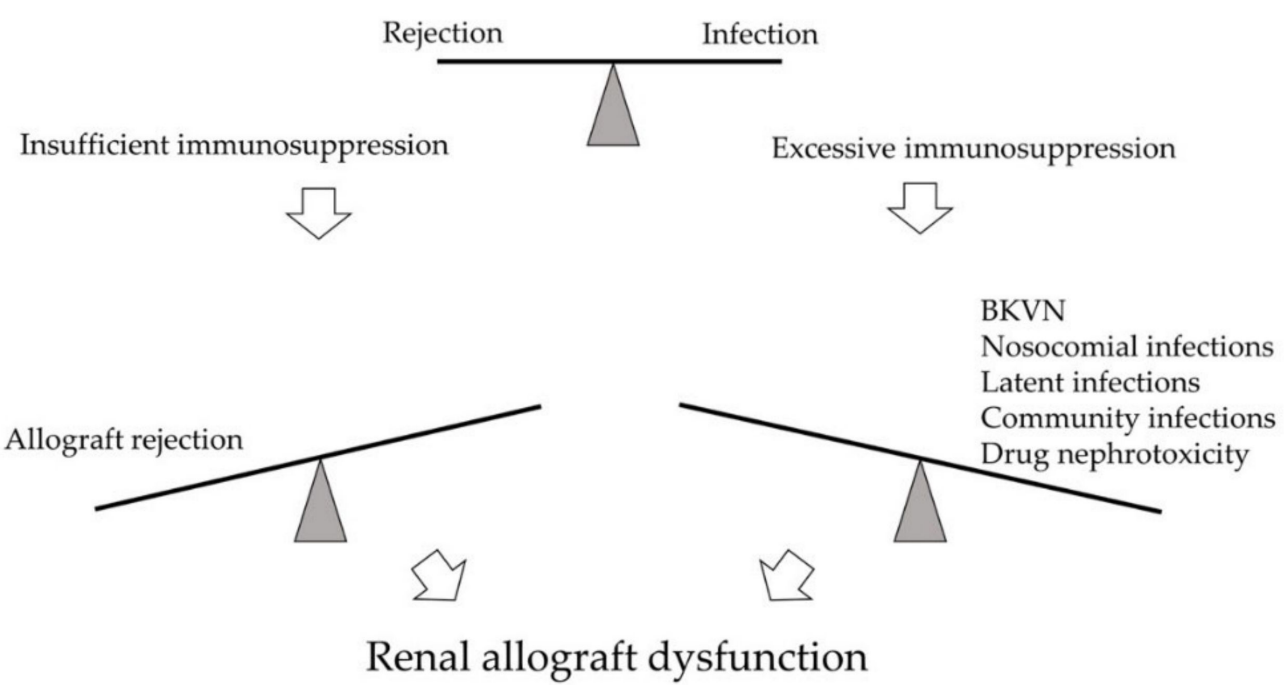

Figure 1. The immune system of kidney transplant recipients is balanced between rejection and infection. Excessive immunosuppression may lead to infections, such as BK polyomavirus nephropathy $(B K V N)$, nosocomial infections, latent infections, and community infections. Drug nephrotoxicity may also develop. On the opposite side, insufficient immunosuppression may result in allograft rejection. Both arms may cause significant kidney damage and renal allograft dysfunction.

\section{About the BKPyV}

$\mathrm{BKPyV}$ is a highly prevalent polyomavirus specific to the human host [4]. As a doublestranded DNA virus, its genome consists of the early coding region, late coding region, and a non-coding control region (NCCR) in between [5]. The early region usually codes for the replication proteins, including the small tumor antigens, the large tumor antigens (TAgs), and agnoprotein. The late region codes for structural proteins VP1, VP2, and VP3 [6]. The microRNAs expression was transcribed from the $3^{\prime}$ end of the TAgs and act as a regulator in BKPyV infection [7]. The NCCR contains the genome of promoters of the early and late regions, transcriptional start sites, and the origin of replication. It also provides binding sites for host cellular regulatory factors. NCCR variation exists between $\mathrm{BKPyV}$ isolates, and the rearranged forms of NCCR are associated with disease [8]. The high heterogeneity of NCCR allows for environmental adaptation and higher pathogenicity for disease progression [6].

Cellular immunity is critical for the immune response during BKPyV viremia and BKVN. Innate immune response serves as the first line of defense against the primary infection [9]. Dendritic cells are critical in the induction of adaptive immune response [10]. Womer et al. reported that the number of peripheral blood dendritic cells is lower in KTRs developed BKVN. They also revealed that KTRs with fewer dendritic cells before transplantation are more likely to be associated with BKVN [11]. Furthermore, BKPyV can decrease the natural killer cell-mediated cytotoxicity by inhibiting the identification of natural killer cells [12]. Other innate immune mediators are associated with renal inflammation [13]. Adaptive immune response develops after exposure to viral antigens. Humoral response works via neutralizing antibodies to defend the further viral infectious process. Studies showed seronegative recipients have higher risks in viremia and subsequent BKVN than seropositive recipients as humoral immunity may help limit BKPyV infection [14-19]. Meanwhile, recipients paired with seropositive donors have a higher post-transplant $\mathrm{BK}$-specific-antibody titer than the seronegative donor group [20]. It means that $\mathrm{BKPyV}$ infection from the donor can induce the humoral immune response [21]. However, the 
virus can hide away from neutralization with a mutation in viral antibody receptors [22,23]. In this situation, latent viral reactivation can be well-controlled by antiviral memory $\mathrm{T}$ cells [4]. Cellular immunity offers more effective infection control because of pathogen detection and cytotoxicity [21]. Both CD4+ and CD8+ T cells are important, especially the polyfunctional BKPyV-specific T cells [24,25]. After kidney transplant, KTRs with viruria but no viremia have positive BKPyV-specific $\mathrm{T}$ cell response [26]. Conversely, there is no BKPyV-specific T cell response in KTRs with BKPyV viremia or BKVN [26-30]. Also, quick BK-specific $T$ cell response was noted in the viremia-resolved group, while the response was only noted after reduced IS in the developed BKVN group [28,31]. These studies concluded that it is crucial for KTRs to reconstitute the BKPyV-specific $\mathrm{T}$ cells to fight against BKPyV infection.

During the first decade of childhood, the primary exposure to $\mathrm{BKPyV}$, often with subclinical symptoms, resulted in 80-90\% of adults developed antibodies against BKPyV [32,33]. The natural transmission route is still unknown [34]. After the primary infection, the virus remains latent in the kidney, peripheral-blood leukocytes, and possibly the brain [35]. The viral reactivation occurs while the host immunity is over-suppressed, resulting in viral replication with consequent tubular cell lysis and viruria. BKPyV replication ensues in the renal interstitium, leading to the destruction of the tubular capillary wall subsequently cross into the blood, causing viremia. Viral invasion of tissue progressively cause cell necrosis and tissue inflammation [36]. BKPyV reactivation presented as viremia usually happens in the first month post-transplant in KTRs. The incidence peaks around 28-31\% at month 3 and month 12 after kidney transplantation, with cases rarely seen at month 18 [37,38]. In the KTR population, the incidence of $\mathrm{BKPyV}$ viruria is $30-40 \%$, BKPyV viremia is $13 \%$, and $\mathrm{BKVN}$ is $8 \%$ [39]. High-level $\mathrm{BKPyV}$ viruria progress to viremia after a median of 4 weeks, and approximately a median of 8 weeks later, viremia may lead to BKVN $[40,41]$. The clinical presentation of BKPyV infection may range from asymptomatic to progressive renal function decline, and others are incidental findings at protocol allograft biopsy [42]. The laboratory clues may be ranged from normal results to elevated serum creatinine, mild proteinuria $(48 \%)$, or hematuria (19\%) [43]. Without screening and treatment, the natural course of BKVN leads to $50 \%$ graft loss $[44,45]$.

\section{Screening and Diagnosis}

Early diagnosis of BKVN usually results in better allograft survival than the advanced disease $[43,46]$. Due to limited treatment options, screening for BKPyV replication is recommended to avoid further kidney histologic involvement. Intensive screening by measuring blood BKPyV DNA can help patients at risk of BKVN preserve allograft function [47,48]. Monitoring of disease progression can be done through urine or blood polymerase chain reaction (PCR). The threshold value of urine viral load is $1 \times 10^{7}$ copies $/ \mathrm{mL}$. Viruria has a negative predictive value of $100 \%$ for $\mathrm{BKVN}$, a positive predictive value of $31-67 \%$, a sensitivity of $100 \%$, and a specificity of $92-96 \%$ [48]. The threshold value of blood PCR is $1 \times 10^{4}$ copies $/ \mathrm{mL}$. Viremia has a negative predictive value of $100 \%$ for BKVN, a positive predictive value of $50-82 \%$, a sensitivity of $100 \%$, and a specificity of $88-96 \%$ [44,49]. The higher positive predictive value of viremia over viruria explains the 2019 Guidelines from the American Society of Transplantation Infectious Diseases Community of Practice (ASTIDCOP), which suggested all KTRs should be screened for blood BKPyV DNA monthly until month 9 and then every 3 months until 2 years post-transplant [50]. Decoy cells, infected tubular epithelial cells identified by the urine cytology examination, are also standard screening methods but wholly depend on pathologists' experience [49]. A Japanese study showed an increasing trend of decoy cells in the BK viremia group and suggested decoy cells can predict early BKPyV infection with continuous and careful monitoring [51]. Additionally, the 2009 KDIGO guideline indicated that in the case of unexplained allograft dysfunction or recent IS dosage increases, one should be cautious of BKPyV [52].

The diagnosis of BKVN relies on clinical judgment and pathological morphologic diagnosis [43]. Presumptive nephropathy, meaning a primary diagnosis without histologic 
confirmation, is defined as plasma BK viral DNA PCR load $>10,000$ copies $/ \mathrm{mL}$ with urinary viral shedding for more than 2 weeks with or without renal function decline [53]. However, once suspected of renal function decline or possible acute rejection, renal biopsy should still be performed before reducing IS dosage [50]. Morphological diagnosis by light microscopy is limited due to similarities between early BKVN and other diagnoses such as acute rejection or calcineurin inhibitor (CNI) toxicity. Definite diagnosis of BKVN can be achieved through a cytopathic change of tubular epithelial cells combined with in situ hybridization against SV40 or Tag [54]. A unified diagnostic criterion is crucial for the comparability of different studies. However, previous morphology diagnosis classification is yet to provide statistical discriminative power for the clinical correlation sufficient enough to revise the classification [55]. AST-IDCOP revised the histological classification with a more detailed description of the degree of interstitial inflammation and the area of the biopsy tissue in 2013 [56]. Banff 2017 working group enrolled multicenter retrospective study analyzed confirmed BKVN systematically to develop a morphologic classification. Intrarenal BKPyV viral load and the Banff interstitial cortical fibrosis score are two independent factors with a significant correlation with clinical presentation and graft outcome [43]. AST-IDCOP 2019 recommended that histological findings of proven BKVN be reported based on AST-IDCOP 2013 and the Banff 2017 classification [50]. As for cases with coexisting BKVN and acute rejection, tubulitis and peritubular inflammation examination by immunohistochemistry and electron microscopy should be performed. The presence of endarteritis, fibrinoid vascular necrosis, glomerulitis, or C4d deposits along peritubular capillaries should be documented for the diagnosis of coexisting BKVN and acute rejection [57-59].

\section{Balancing the Rejection and Infection}

BKPyV reactivation is induced by relative or absolute immunodeficient status, such as pregnancy, cancer, HIV infection, and diabetes [60]. Typical BKPyV reactivation occurs early after transplantation or after over immunosuppression [61]. BKPyV infection or reactivation can be managed by balancing the immune system. In other words, IS dose should be delicately reduced to avoid allograft rejection. In this part, we discuss methods to reduce the possibility of infection or reactivation in addition to the management strategies of BKPyV infection.

\subsection{Risk Factors for BKPyV Infection or Reactivation}

Risk factor identification for $\mathrm{BKPyV}$ is essential. The studied risk factors for $\mathrm{BKPyV}$ infection can be assorted into several categories: Donor risk factors, recipients risk factors, and transplant risk factors (Figure 2) [16,18,39,56,62-72]. A systemic review revealed the most relevant risk factors for $\mathrm{BKPyV}$ viremia after kidney transplantation were a tacrolimus regimen, a deceased donor, a male recipient, a history of the previous transplant, age at transplantation, ureteral stent use, delayed graft function, and acute rejection episodes [73]. Due to the low frequency of the BKVN, the sample size of each study is small; therefore, it is difficult to reach statistically significant results in BKVN studies. Prince et al. enrolled 34 BKVN patients in a single-center and reported that tacrolimus, mycophenolate mofetil (MMF), and acute rejection were significant risk factors for BKVN [74]. Pai et al. published another single-center retrospective study, where $14 \mathrm{BKVN}$ patients were assessed for associated risk factors of BKVN. Episodes of rejection, transplantation of $>1$ organ, positive cytomegalovirus (CMV) serology in both donor and recipient, and a more significant cumulative dose of daclizumab use at the time of induction were statistically significant risk factors for the development of BKVN [69]. Prince et al. suggested that BKVN only manifests while the host immunity is over-suppressed, whereas acute rejection independently plays a role regardless of therapeutic regimens [74]. Hence, understanding pre- and post-transplant risk factors can be helpful to balance the infection and rejection. 


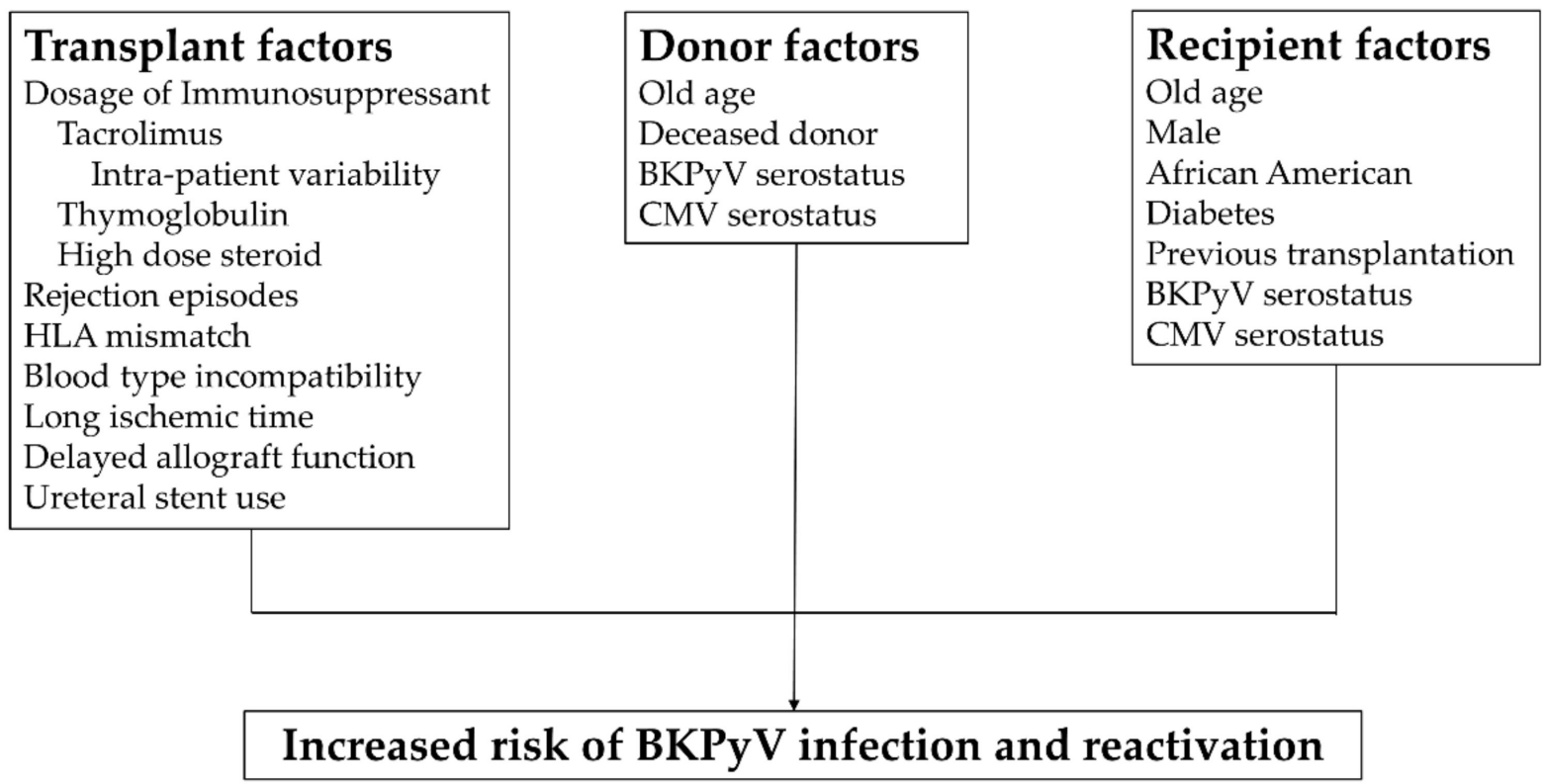

Figure 2. Risk factors for BKPyV infection. Risk factors can be assorted into 3 categories: Transplant factors [39,56,62-65,67,68,70-72], donor factors $[16,18,62,64,66,69]$, and recipient factors $[16,18,56,64,69]$. Understanding risk factors that affect before and after transplant can be helpful in immune balance. Abbreviations: HLA, human leukocyte antigen; BKPyV, BK polyomavirus; CMV, cytomegalovirus.

Tacrolimus itself is a potent IS compared with cyclosporine with less acute rejection rate, as evident by a phase III multicenter trial [75]. A meta-analysis showed less graft loss, less acute rejection rate, and less steroid-resistant rejection when compared with cyclosporine [76]. Among all the IS, emerging data suggest that tacrolimus use possesses the greatest risk for BKVN [77]. Hirsch et al. analyzed the DIRECT trial, which compared tacrolimus to cyclosporine in a combined regimen prospectively. A higher incidence rate of BK viremia in the tacrolimus group 6 months after transplant was reported [47]. Benavides et al. [77] and Moscarelli et al. [78] both found that mammalian target of rapamycin (mTOR) inhibitor is less likely to be associated with BK viremia and BKVN. Hirsch et al. reported mTOR inhibitor sirolimus could inhibit BKPyV replication during gene expression while tacrolimus plays a role in activating replication via FK binding protein-12 $\mathrm{kDa}$ [79]. This study provides rationales for the further clinical trial of anti$\mathrm{BKPyV}$ therapy. Ureter stent use is another crucial transplant risk factor not related to immune status, especially for postoperative recovery. The association between ureteral stents and $\mathrm{BKPyV}$ is well documented because tubular and urothelial cell injury allows for BKPyV replication $[70,71]$.

Both BKPyV serostatus of donor and recipient are important risk factors. Wunderink et al. published the largest research to date showing that donor seropositivity was strongly associated with the occurrence of recipient viremia and BKVN $(p<0.001$, Student's $t$-test). The results also pointed out that when high-BKPyV-seroreactive donors are paired with lowseroreactive recipients, the recipients have a 10-fold increased risk of BKPyV viremia [16]. $\mathrm{BKPyV}$ serostatus can be used as a method for risk stratification for BKPyV reactivation. Sood et al. showed that viremia is the highest in the donor-seropositive-recipient-positive group but is the lowest in the donor-seronegative-recipient-seronegative group [18]. These studies show strong evidence for donor-origin BKPyV infection as a vital transmission source. Several other studies reached the same conclusion through ELISA or neutralization inhibition assays $[15,17,19,80-82]$. An additional clinical guideline may be needed to define serostatus, cut-off values, and standard testing methods for clinical use. 


\subsection{Tacrolimus Dosage Monitoring}

Tacrolimus, a potent immunosuppressor, decreases the incidence rate of early acute rejection and graft failure rate $[82,83]$. Tacrolimus drug-level monitoring is important in post-transplant care because of the pharmacological properties: Non-linear concentrationeffect relationship, narrow therapeutic window, and nephrotoxicity [84]. Other related issues include metabolic side effects, CNI nephrotoxicity, and over-suppression-related opportunistic infection. Moreover, inter-patient variability and intra-patient variability may cause fluctuation of blood tacrolimus level even with stable prescription dosage [85]. Outcome-association between the drug-level and graft function is evident [86-89]: Insufficient tacrolimus may increase rejection risk while overdosing brings possible toxicity and infection [90]. Tacrolimus trough level $>10 \mathrm{ng} / \mathrm{mL}$ is associated with BKPyV infection after kidney transplantation [66]. Due to the reasons stated above, an optimal method to tailor IS dosage with proper monitoring is a topic worth exploration.

Trough-level monitoring of tacrolimus is the standard of care in clinical practice. The result of a clinical phase III trial indicated a trough level between $10-15 \mathrm{ng} / \mathrm{mL}$ during the 3-month-period after transplantation and 5-10 $\mathrm{ng} / \mathrm{mL}$ afterward [91]. A meta-analysis of 10 studies and almost 6000 individuals showed maintaining tacrolimus blood concentration at $5-9.5 \mathrm{ng} / \mathrm{mL}$ within the first year may be the most effective method to prevent acute rejection [92]. Steroids are cytochrome P3A (CYP3A) inducer, and tacrolimus is involved in the cytochrome P450 catalytic cycle. Tacrolimus level may increase when high dose steroid is used. Once the steroid is tapered, tacrolimus may become overdosed with consequent nephrotoxicity [93]. The Symphony study minimized tacrolimus dose and observed that a lower tacrolimus level (3-7 ng/mL) combined with daclizumab induction, MMF, and steroids, possessed the lowest risk of acute rejection at month 12 post-transplant. This suggested that tacrolimus blood level can be lower than usual when combined with an mTOR inhibitor in the maintenance stage [94]. Difficult dosage titration in a complex clinical situation should be managed by an experienced kidney transplant specialist in a high-volume medical center.

\subsubsection{Inter-Patient Variability of Blood Tacrolimus Level}

Tailored usage of tacrolimus requires delicate clinical adjustments based on drug-level monitoring due to the inter-patient variability. The inter-patient blood tacrolimus level varies because of individual-specific pharmacokinetics and pharmacogenetics. Factors affecting inter-patient heterogeneity include age, race, hepatic dysfunction, blood albumin, hematocrit, and diurnal rhythm [95]. Higher tacrolimus doses are needed for pediatric patients to reach the same trough level, likely due to the higher CYP3A gene expression in children [96,97]. African-American recipients need higher tacrolimus doses due to reduced bioavailability, suggesting racial differences in intestinal CYP3A or P-glycoprotein activity [98-100]. Because tacrolimus strongly binds to red blood cells and albumin, its trough level seems to be lower after the transplant but is then elevated after patient recovery [101]. As for the diurnal rhythm, the higher daytime clearance is probably due to the circadian effect on gastric emptying time and intestinal perfusion for drug absorption $[102,103]$.

\subsubsection{Intra-Patient Variability of Blood Tacrolimus Level}

Generally, intra-patient variability (IPV) is the fluctuation in tacrolimus trough concentrations of a single individual with unchanged tacrolimus dose over a period of time. On average, the tacrolimus IPV is between $15 \%$ and $30 \%$, while others reported a wider IPV range from lower than $5 \%$ to over $50 \%$ [85]. Several determinants may contribute to IPV; the impact from high to low include medication nonadherence, drug-drug interaction, nutritional interferences, concurrent disease, analytical assay, genetics, and generic tacrolimus substitution [104]. Nonadherence to the IS drug is the most common and the main determinant factor of high tacrolimus IPV. A meta-analysis pointed out a 7-fold risk of graft failure between nonadherent and adherent groups [105]. Macrolide antibiotics, azole antifungals, rifampin, glucocorticoids, calcium channel blockers, and anti-epileptic agents 
may influence the tacrolimus IPV by altering the CYP3A activities. Patients should avoid over-the-counter drugs, grapefruit, pomelo, high-fat meal, and concomitant food ingestion [106-110]. Illnesses like diarrhea, anemia, hypoalbuminemia, and hyperlipidemia are related clinical problems [111]. When no obvious interference factor is found, the genetic difference might explain the fluctuation [112].

Multiple large studies have demonstrated significant negative consequences of the high tacrolimus IPV, including graft survival, acute rejection, de novo donor-specific antibody (dnDSA), and chronic immunologic-mediated graft injury. The first long-term outcome study by Borra et al. reported that high tacrolimus IPV was related to 1-year posttransplant graft function decline [113]. Shuker et al. enrolled a larger cohort study with primary endpoints, including graft failure, late biopsy-proven acute rejection, transplant glomerulopathy, or doubling time of serum creatinine concentration. The result revealed that a high tacrolimus IPV was an independent predictor of inferior graft outcomes [114]. Likewise, Rozen-Zvi et al. showed a higher mean tacrolimus IPV (mean IPV $34.8 \pm 21.3 \%$ ) was associated with worse graft survival within the 6-month post-transplant phase [115]. Ro et al. were the first to present an association between high tacrolimus IPV and acute rejection risk [116]. In our study, high tacrolimus IPV was associated with coexist acute rejection and BKVN [67].

Further research may aim to quantify IPV as a scale for surveillance and reduce acute rejection incidence [117]. Meanwhile, evidence was connected to tacrolimus IPV with dnDSAs and antibody-mediated rejection. A Spanish study with 6.6 years of follow-up was designed to evaluate the incidence of dnDSAs and graft survival in relation to tacrolimus IPV. The primary endpoint showed dnDSA development was associated with worse graft survival $(p<0.001)$, while tacrolimus IPV was associated with dnDSA development $(p=0.002)$. The secondary endpoint showed high tacrolimus IPV associated with an increased risk of graft loss. To sum it up, tacrolimus IPV is an independent factor for graft loss and a strong risk factor for dnDSA development [118]. Sablik et al. found that recipients with chronic active antibody-mediated rejection showed a significant association with lower allograft survival in the high tacrolimus IPV group [119]. Vanhove et al. designed a study according to protocol biopsy and IPV tertiles to provide a direct and robust histology link to clinical correlation. They proved a positive association between tacrolimus IPV and the evolution of acute on chronic histologic lesions. It suggested that tacrolimus IPV monitoring can predict chronic histologic lesions' progression before the onset of renal dysfunction [120]. Gradually it became clear that high tacrolimus IPV is related to acute and chronic rejection, dnDSA formation in high immunologic risk recipients, histological fibrotic change, and poor allograft outcome.

The current clinical focus of tacrolimus IPV is the reduction of IPV, a standardized formula to calculate tacrolimus IPV, and whether decreasing IPV improves outcome or not. As high tacrolimus IPV can cause coexistent acute rejection and BKVN, this clinical application matches our topic. Reduction of IPV in practice may include careful drug usage with food or other drugs and regular drug usage without skipping doses. Previous phase III and IV studies in de novo initiation confirmed the same medicinal effect of once-daily and twice-daily tacrolimus in preventing acute rejection and graft loss [121-124]. Some Investigators focused on switching twice-daily tacrolimus to a once-daily formulation for better adherence, and the result favored the once-daily extended-release tacrolimus $[125,126]$. The first prospective randomized control trial by McGillicuddy et al. adjusted the nonadherence by electronics significantly decreased tacrolimus IPV [127]. Future studies are warranted for the impact of reducing tacrolimus IPV on graft outcome. Also, a delicate cut-off value of the variability should be identified for better patient risk evaluations and clinical tacrolimus adjustment. In terms of a cut point, patients with tacrolimus IPV $>30 \%$ or $>40 \%$ should be considered to be at high risks for BKVN by experts' opinions [128]. 


\subsection{Other Immunosuppressants}

The current standard triple regimen tacrolimus-mycophenolate mofetil-steroid is originated from several clinical trials in decades with the advantages of lower rejection rate, or lower required IS dosage. A meta-analysis comparing cyclosporine and tacrolimus reported tacrolimus significantly reduced graft loss and acute rejection rates, but there was no difference in infection between the two groups [76]. In patients with persistent viremia after reducing all the IS, shifting from tacrolimus to cyclosporine is an alternative strategy to alleviate concerns over insufficient immunosuppression [47]. Kim et al. found that high-dose steroid (cumulative intravenous steroids $>2 \mathrm{~g}$ within 30 days) may increase BKPyV infection and result in poor long-term graft function [68]. Hirsch et al. found that BKPyV replication within renal tubular epithelial cells is inhibited by sirolimus but is activated by tacrolimus through a pathway involving FKBP-12 [129]. Clinical studies revealed sirolimus-based IS regimen does indeed inhibit BKPyV with a lower incidence rate of BKPyV infection $[62,130]$. A prospective, controlled study reported that an everolimusbased IS regimen with CNI minimization and MMF discontinuation effectively treated BKVN in KTRs [131]. As for the role of MMF in BKPyV infection, though MMF use has been reported as a risk factor [74], most studies revealed no direct association. Therefore, it remains a controversial topic [132].

\subsection{Risk Factors for Acute Rejection}

Risk factors for acute rejection are important for BKPyV management, especially for the clinical differentiation of renal dysfunction. Pre-transplant donor-specific antibody and HLA mismatch are, respectively, main predictors of antibody-mediated rejection and $\mathrm{T}$ cell-mediated rejection [133]. The regimen of IS is the determining factor for the posttransplant risk of acute rejection. Reducing or replacing tacrolimus with an add-on mTOR inhibitor may increase the acute rejection rate [134]. A cohort study with tacrolimus-based triple IS regimen reported mean tacrolimus level $<8 \mathrm{ng} / \mathrm{mL}$ in the first year has a strong association of increased DSA development $(p=0.005)$. Mean tacrolimus $4-6 \mathrm{ng} / \mathrm{mL}$ may increase acute rejection rate 2.3-fold compared with the $8 \mathrm{ng} / \mathrm{mL}$ group [135]. Other risk factors may include younger recipient age, older donor age, African-American ethnicity, delayed onset of graft function, and cold ischemic time over $24 \mathrm{~h} \mathrm{[52].}$

\subsection{Biologic Marker Development in BKVN}

While indirect examinations such as creatinine, drug trough level, and urine analysis can provide limited information, the definitive method for BKVN diagnosis is still renal biopsy. Ongoing research and the development of new non-invasive monitoring measurements provide promising biomarkers to assist the definite diagnosis of BKVN. It has been reported that urinary exosomal BK viral microRNA, bkv-miR-B1-5p and bkvmiR-B1-5p/miR-16, have excellent statistical significance for the diagnosis of BKVN, with the area under the curve values of 0.989 and 0.985 , respectively [136-138]. Dvir et al. hypothesized the association of the interferon- $\lambda$ family with BKVN due to the antiviral protection of the epithelium. They found a single-nucleotide polymorphism rs12979860 in the genomic region of interleukin-28B has predictive value for identifying high-risk patient progression from viremia to BKVN [139]. Ho et al. described the correlation of urine C-X-C motif chemokine ligand 10 (CXCL10) with BK viremia. The urine CXCL10 represents subclinical inflammation within tubular-interstitial and peritubular capillary spaces in the study [140]. The challenge faced during biomarker development of BKVN is the overlapping pathogenetic mechanisms of BKVN with other allograft injuries, such as rejection and tubular interstitial fibrosis. There are still no mature biomarkers yet and need future research for clinical monitoring and guiding optimal IS adjustment [141].

On the other hand, biomarkers for acute rejection may still be helpful for disease differentiation. Ongoing research for biomarkers intended for the diagnosis, exclusion, or confirmation of acute rejection. Suthanthiran et al. reported a molecular signature of CD3 $\varepsilon$ mRNA, IP-10 mRNA, and 18S rRNA levels in urinary cells that appear to be diagnostic and 
prognostic of acute cellular rejection in kidney allografts [142]. Urinary chemokines C-X-C motif chemokine ligand 9 (CXCL9) and CXCL10 are the most well-developed biomarkers for T-cell mediated rejection and acute antibody-mediated rejection [143-146]. KTRs with low urinary CXCL9 protein levels within the 6-month post-transplant period were less likely to experience future acute rejection between 6 and 24 months (NPV 92.5-99.3\%) [144].

Meanwhile, plasma donor-derived cell-free DNA (ddcfDNA) fractions decreased exponentially within 10 days after transplantation to a ddcfDNA threshold value of $0.88 \%$ or less. An increase above the reference baseline of $0.88 \%$ was associated with acute rejection, but acute pyelonephritis and acute tubular necrosis cannot be excluded [147]. Many other non-invasive ongoing biomarkers are under investigation, and randomized control trials are needed for future implementation into clinical practice.

\section{Strategies of Immunosuppression Reduction}

When a KTR's immune system is over-suppressed, the incidence of infection increases. Aggressive dosage reduction of IS help immunity recovery, protect allograft outcome, and save lives. Our group studied the timing of the first IS drug reduction of the Pneumocystis jiroveci pneumonia survivors and found that a prompt and sufficient reduction of IS dosage significantly improved mortality with minimal risks of in-hospital and long-term acute rejection [148]. Additionally, we also examined KTRs who suffered from severe bacterial pneumonia with respiratory failure and acute kidney injury. Our study showed a minimal risk of acute rejection during 2-year follow-up with a trend, though not significant, improved in-hospital mortality [149]. Both studies reflect that immunosuppression reduction is the right side to choose when facing severe infection in kidney transplants.

According to the KDIGO guideline in 2009, reduction of immunosuppression for $\mathrm{BKPyV}$ infection in KTR is still the primary treatment to date (Figure 3) [52]. Any concurrent or increase risk of acute rejection should be taken into consideration. There are no standard regimens, and the outcomes vary between institutes. Currently, there are only metaanalyses and prospective observational studies. A systematic review analyzed 8 cohorts and 13 case-series, showing that a IS reduction alone strategy without additional anti-viral drug use may achieve a relatively low graft loss rate of 0.08 per patient-year in patients with BKVN [150]. Clinically, common stepwise strategies are as follows:

- A once or twice dose reduction of the CNI by $25-50 \%$, with target tacrolimus trough level $<6 \mathrm{ng} / \mathrm{mL}$ followed by reducing the antimetabolite drug by $50 \%$, and lastly discontinuing the latter in the case of high viral load [40].

- Decrease the antimetabolite drug by $50 \%$ or discontinuation, then decrease CNI by $25 \sim 50 \%$ if viremia does not resolve [48].

- $\quad$ Reducing both the CNI and the antimetabolite drug simultaneously [151].

Rejection may happen, or donor-specific antibodies may develop due to different responses from individuals. Close monitoring of blood creatinine, plasma BK viral loads, and calcineurin inhibitor levels are required. Donor-specific antibody and blood viral load PCR can be followed up for evaluations [152]. Coexisting acute allograft rejection should be concerned, and renal biopsy should be performed once serum rises with viral load decline.

Recent single-center retrospective studies were followed for a longer duration with a higher case number compared to previous reports. Since no randomized prospective trial has been conducted, the current understanding is based on rationale from large cohort studies. Most of these study designs are separated into two groups: Taper CNI in the first step (CNI first) or taper antimetabolite agent first. Sawinski et al. reported a 3 year-follow-up study showing that decreasing antimetabolite agent first posed no differences in patient and allograft survival rates between patients with and without BK viremia [153]. Seifert et al. also firstly reduced antimetabolite agents in a 10-year cohort and found that the mortality rate was slightly higher in the BK viremia group. However, no differences in rejection rate, death-censored graft survival, and graft function were noted [154]. Bischof et al. retrospectively examined a 6-year cohort and found that the reducing CNI first strategy led to similar long-term outcomes between patients with and without BK 
viremia, but reducing CNI first posed a low risk for ABMR after viremia clearance [155]. Baek et al. published a 6-year retrospective cohort study that concluded CNI dose reduction by $>20 \%$ at 1 month after the initial BKPyV detection could increase the risk of acute rejection [156]. Different combination regimens balancing rejection and infection depend on the on-target and off-target properties. CNIs block T cells' signal transduction that impaired cytokine secretion while mTOR inhibitors or antimetabolite agents do not [157]. Renner et al. showed that the tacrolimus and MMF-based combination increased the risk of $\mathrm{BKPyV}$ viremia, which became not different from the cyclosporine/MMF group when tacrolimus was converted to everolimus [24]. As mentioned above, the mTOR inhibitor suppresses BKPyV replication in vitro while tacrolimus activates virus production [79]. Since there is no consensus on using either CNI or MMF reduction strategies, further randomized trials are expected. Schwarz et al. retrospectively studied the influence of different variables on the glomerular filtration rate of BKVN. The authors divided the patients into CNI reduction group, MMF reduction group, CNI shift to mTOR inhibitor group, and CNI shift to mTOR inhibitor as a second-step group. The result showed rapid viral load reduction has a significant association with stable or increasing GFR, regardless of which kind of reduction strategies ( $p=0.0004$, Log-rank test) [158]. This result was also compatible with the aforementioned studies [148,149].

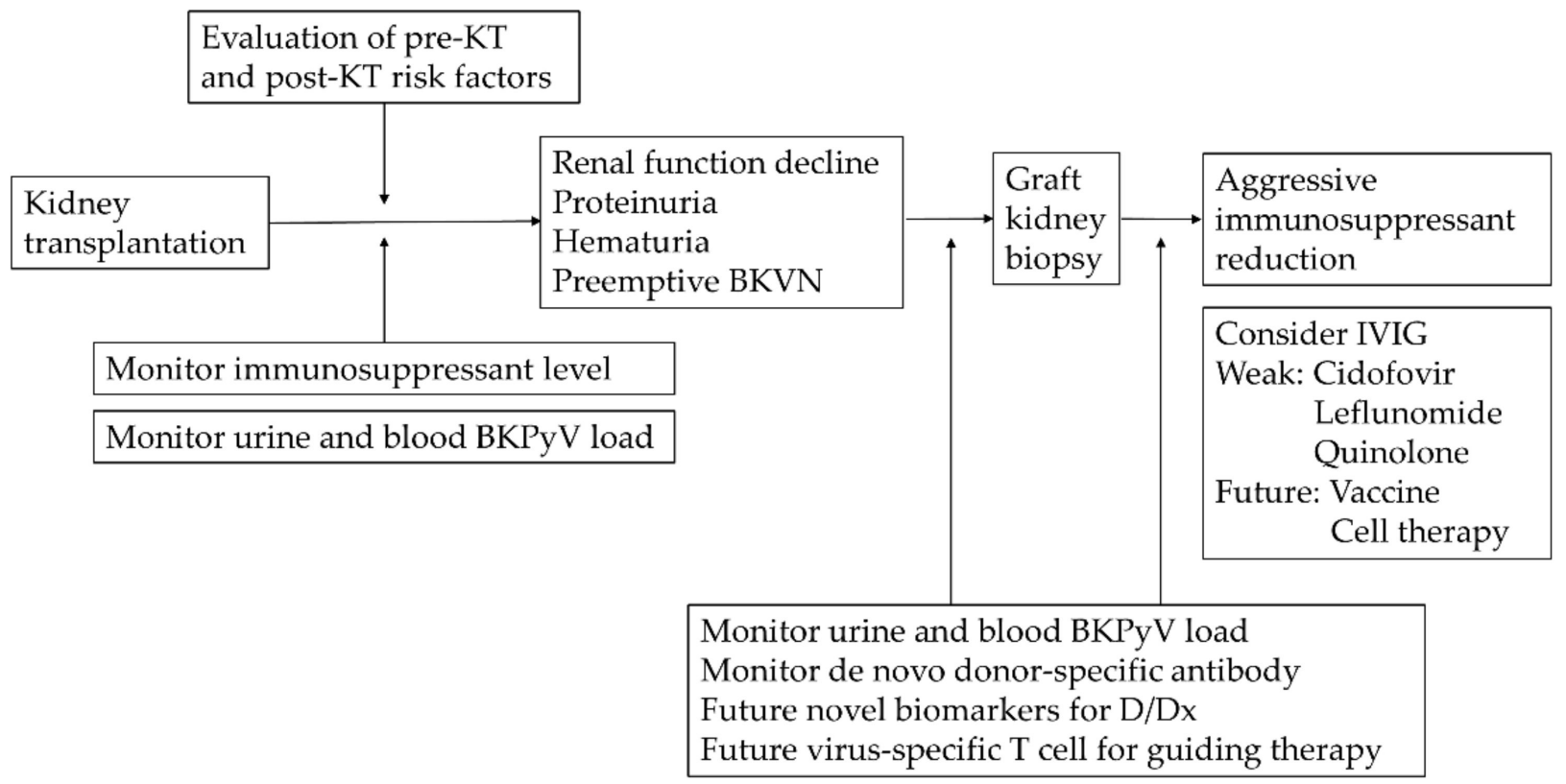

Figure 3. Conceptual illustration of evaluations, screening, diagnosis, and management for BKPyV infection. Abbreviations: $\mathrm{KT}$, kidney transplant; $\mathrm{BKPyV}$, BK polyomavirus; $\mathrm{BKVN}$, BK polyomavirus nephropathy; IVIG, intravenous immunoglobulin; D/Dx, differential diagnosis.

Due to the lack of direct markers for renal transplant recipient immunity, the remaining option is to adjust the IS dosage by evaluating indirect assessments such as creatinine, urine, blood BKPyV DNA PCR, and donor-specific antibodies individually. Torque Teno virus (TTV), a nonpathogenic and ubiquitous virus, has gained attention to be a potential marker of immune function in solid organ transplantation $[159,160]$. The replication and clearance of commensal TTV viral load were under close control of our immune system [161]. IS after transplant impaired the balance, and TTV was found to increase after excessive immunosuppression $[159,162]$. TTV viral load also increases when patients are co-infected with other pathogens and in patients who have autoimmune inflammatory diseases [163-167]. This correlation provides a rationale for TTV being a promising marker of the net immunosuppression state. Schiemann et al. demonstrated that lower TTV viral load was independently associated with antibody-mediated rejection [168]. Current 
prospective studies revealed the value of TTV quantification for risk stratification of kidney graft rejection or infection. It might be used as a monitoring tool but not a diagnostic tool yet [169-171]. However, a study claimed that there is no relationship between BKPyV replication and TTV viral load [172]. Further prospective studies are warranted to confirm the clinical values of TTV quantification and its clinical use, including optimal TTV range, international unity, and hard clinical outcome prediction.

By measuring virus-specific $\mathrm{T}$ cell levels in pediatric post-transplant care, steering IS was presented in the IVIST trial results recently. A multicenter, randomized, controlled trial enrolled 64 pediatric KTRs. They monitored trough level in both groups and virusspecific T cell levels in the intervention group for IS dosage adjustment [173]. Compared to control groups, both everolimus and cyclosporine's dosage was reduced in the intervention group with no difference in renal function 2 years after transplantation. Both trough levels of everolimus and cyclosporine were significantly lowered. Besides, patients in the intervention group were more likely to be spared from glucocorticoid use at 2-year post-transplant.

Meanwhile, fewer acute rejection events, similar de novo donor-specific antibody development, viral infection (CMV, herpes simplex virus, Epstein-Barr virus (EBV)), and BKVN were noted in the intervention group [173]. This study provides a safe measurement other than the pharmacokinetic method for personalizing dosing and IS reduction. That means we can avoid CNI toxicity or the side effect of long-term steroid use. Future larger trials focusing on prevention overimmunosuppression for adult transplant recipients with a standard triple regimen consisting of tacrolimus, mycophenolate mofetil, and steroid are expected. The IVIST trial may be a paradigm shift for immunoassay-guided optimal immunosuppression in future clinical practice [173].

\section{Novel Treatment for BKVN}

\subsection{Immune Therapy}

\subsubsection{Intravenous Immunoglobulin}

The therapeutic mechanisms of intravenous immunoglobulin (IVIG) for BKVN are not fully understood. Both donated and commercial IVIG contains IgG against various infectious diseases, including BKPyV neutralizing antibodies [174,175]. Meanwhile, IVIG has powerful indirect immunomodulatory effects $[176,177]$. Successful case series of viremia-lowering adjunctive therapy with IVIG had been reported after the failure of IS dose reduction and leflunomide administration [178-180]. An additional IVIG group presented cleared viremia and $\mathrm{BKPyV}$ immunohistochemistry evident from repeated tissue sampling [181]. A recent study showed significant increasing BKPyV genotype-specific neutralizing antibody titers in KTRs [182]. A retrospective study showed prophylactic IVIG in the early post-transplant phase was associated with a significantly lower incidence of both BKPyV viremia and BKVN in high-risk recipients [183]. Further randomized control trials are in expectancy in this field for more substantial evidence of IVIG efficacy.

On the other hand, IVIG is also the most common therapy for antibody-mediated rejection in adjunct with plasmapheresis and/or rituximab. The plasmapheresis removes the donor-specific antibodies, and IVIG exerts immunomodulatory effects on the antibodies. A meta-analysis included 21 articles of antibody-mediated rejection since 1950, showing insufficient evidence of all kinds of treatments due to each article's small sample size [184]. Lefaucheur et al. conducted a randomized trial that compared IVIG only or IVIG combined plasmapheresis and rituximab. The high graft loss rate in IVIG alone group indicated IVIG by itself is not enough to prevent antibody-mediated rejection. Due to limited data and sample size of studies in this field, current management for antibody-mediated rejection remains plasmapheresis and IVIG combination therapy [185].

\subsubsection{Cellular Therapy}

The importance of cellular immunity toward BKPyV infection in transplant recipients has been recognized [186]. The BKPyV-specific T cell has drawn much attention, and its 
amount has a positive association with clearing BKPyV viremia in KTRs $[30,187]$. Failure of $\mathrm{BKPyV}$-specific $\mathrm{T}$ cell to control viral replication due to IS overdose results in reactivation of BKPyV infection [188]. Thus, cellular therapy to regain immunity in recipients is a developing field in BKPyV immunotherapy. Owing to the advances in immunological techniques, adoptive $\mathrm{T}$ cell therapy was assisted by synthetic viral peptides to identify BKPyV and MHC antigens. Also, T cell expansion was performed by overlapping peptide pools. The enzyme-linked immunospot (ELISPOT) assay and tetramer staining can measure T cell responses. Many studies aimed to recognize adoptive T cell therapy's safety and toxicity in vitro and in vivo. Papadopoulou et al. used overlapping peptide pools to generate virus-specific $\mathrm{T}$ cells for the commonly detected virus, including $\mathrm{EBV}, \mathrm{CMV}$, human herpesvirus 6 in vitro.

Meanwhile, these virus-specific T cells had successfully treated different viral infections, with a $94 \%$ response rate in 8 hematopoietic stem cell transplant (HSCT) patients without toxicity [189]. A phase II clinical trial showed that administration of BKPyV-specific $T$ cells manufactured from a patient's stem cell donor or unrelated donors could reduce symptomatic infection and BK viral load effectively in HSCT and solid organ transplant (SOT) recipients. A study enrolled 38 HSCT recipients and 3 SOT recipients who developed $\mathrm{BKPyV}$ viremia and/or hemorrhagic cystitis or nephropathy after transplant. The results showed clinical benefits; the overall response rate was $86 \%$ in the BK viremia group and $100 \%$ in the hemorrhagic cystitis group; $87 \%$ of patients in both groups were free of adverse effects, notably without a reduction in IS dose. This study supports further investigation in T cell therapy or even prophylaxis for BKVN [190].

\subsection{Vaccine}

There is no BKPyV vaccine currently, with most in the concept and design phase. Augmenting the humoral or cellular immune response to BKPyV is the central concept [191]. Due to cross-reaction did not exist between BKPyV serotypes, viral capsid protein aggregates instead of viral genetic components are the current approach in vaccine development $[192,193]$. Immunodominant peptides-modified BKPyV has been investigated [194]. Recent research found the multi-epitope vaccine with potential effectiveness may solve problems mention above for wide population use. Although the results are still in the experiment phase, it still displays impressive advances in this field [195].

\section{Conclusions}

BKPyV has a significant impact on kidney allograft during the first year post-transplant. Measures including preemptive monitoring combined with timely IS dose reduction decrease the graft failure rate caused by BKVN. The optimal IS regimen is to balance rejection and infection through delicate clinical evaluations (Figure 3). Meanwhile, evidence suggests that an mTOR inhibitor-based regimen may be beneficial to treat BKVN. Understanding the pre-and post-transplant risk factors helps us reduce complications. The step-by-step nature of international standard guidelines for tailoring IS dosage has its limitation due to ethical dilemmas, subsequent rejection, and graft injury. Direct markers for immunity assessment and direct antiviral agents are further research objectives. With the advances in immunology and biological sciences, we can look forward to a new era in the diagnosis and therapy of BKVN.

Author Contributions: Conceptualization, C.-L.S. and C.-Y.Y.; methodology, C.-L.S. and C.-Y.Y.; software, C.-L.S.; investigation, C.-L.S., B.-S.W., and C.-Y.Y.; resources, T.-J.L., A.-H.Y., and C.-Y.Y.; writing—original draft preparation, C.-L.S. and B.-S.W.; writing—review and editing, C.-Y.Y.; visualization, C.-L.S., B.-S.W., T.-J.L., A.-H.Y., and C.-Y.Y.; supervision, T.-J.L., A.-H.Y., and C.-Y.Y.; project administration, C.-Y.Y.; funding acquisition, C.-Y.Y. All authors have read and agreed to the published version of the manuscript. 
Funding: The authors acknowledge the financial support for research purpose by the "Yin Yen-Liang Foundation Development and Construction Plan" of the School of Medicine, National Yang-Ming University, Taipei, Taiwan (107F-M01-0504), the Ministry of Science and Technology (MOST), Taiwan (MOST 105-2628-B-075-008-MY3, MOST 108-2633-B-009-001, MOST 109-2314-B-010-053-MY3, MOST 109-2811-B-010-532, and MOST 109-2321-B-009-007), grants from Taipei Veterans General Hospital, Taipei, Taiwan (V106D25-003-MY3, VGHUST107-G5-3-3, VGHUST109-V5-1-2, and V110C-194), and the "Center for Intelligent Drug Systems and Smart Bio-devices (IDS ${ }^{2}$ B)" from The Featured Areas Research Center Program within the framework of the Higher Education Sprout Project by the Ministry of Education (MOE) in Taiwan.

Institutional Review Board Statement: Not applicable.

Informed Consent Statement: Not applicable.

Data Availability Statement: The data that support the findings of this study are available from the corresponding author upon reasonable request.

Acknowledgments: We are grateful to our lab member, Pu-Yuan Chang, for his critically reading of the manuscript and stimulating discussions during the preparation of this review.

Conflicts of Interest: The authors declare no conflict of interest. The funders had no role in the design of the study, in the collection, analyses, or interpretation of data, in the writing of the manuscript, or in the decision to publish the results.

\section{References}

1. Parajuli, S.; Astor, B.C.; Kaufman, D.; Muth, B.; Mohamed, M.; Garg, N.; Djamali, A.; Mandelbrot, D.A. Which is more nephrotoxic for kidney transplants: BK nephropathy or rejection? Clin. Transplant. 2018, 32, e13216. [CrossRef] [PubMed]

2. Gardner, S.D.; Field, A.M.; Coleman, D.V.; Hulme, B. New human papovavirus (B.K.) isolated from urine after renal transplantation. Lancet 1971, 1, 1253-1257. [CrossRef]

3. Fishman, J.A. BK virus nephropathy-polyomavirus adding insult to injury. N. Engl. J. Med. 2002, 347, 527-530. [CrossRef]

4. Ambalathingal, G.R.; Francis, R.S.; Smyth, M.J.; Smith, C.; Khanna, R. BK Polyomavirus: Clinical Aspects, Immune Regulation, and Emerging Therapies. Clin. Microbiol. Rev. 2017, 30, 503-528. [CrossRef] [PubMed]

5. Moens, U.; Van Ghelue, M.; Johannessen, M. Oncogenic potentials of the human polyomavirus regulatory proteins. Cell Mol. Life Sci. 2007, 64, 1656-1678. [CrossRef]

6. Helle, F.; Brochot, E.; Handala, L.; Martin, E.; Castelain, S.; Francois, C.; Duverlie, G. Biology of the BKPyV: An Update. Viruses 2017, 9, 327. [CrossRef] [PubMed]

7. Broekema, N.M.; Imperiale, M.J. miRNA regulation of BK polyomavirus replication during early infection. Proc. Natl. Acad. Sci. USA 2013, 110, 8200-8205. [CrossRef]

8. Cubitt, C.L. Molecular genetics of the BK virus. Adv. Exp. Med. Biol. 2006, 577, 85-95. [PubMed]

9. Comoli, P.; Binggeli, S.; Ginevri, F.; Hirsch, H.H. Polyomavirus-associated nephropathy: Update on BK virus-specific immunity. Transpl. Infect. Dis. 2006, 8, 86-94. [CrossRef] [PubMed]

10. Drake, D.R., 3rd; Moser, J.M.; Hadley, A.; Altman, J.D.; Maliszewski, C.; Butz, E.; Lukacher, A.E. Polyomavirus-infected dendritic cells induce antiviral CD8(+) T lymphocytes. J. Virol. 2000, 74, 4093-4101. [CrossRef] [PubMed]

11. Womer, K.L.; Huang, Y.; Herren, H.; Dibadj, K.; Peng, R.; Murawski, M.; Shraybman, R.; Patton, P.; Clare-Salzler, M.J.; Kaplan, B. Dendritic cell deficiency associated with development of BK viremia and nephropathy in renal transplant recipients. Transplantation 2010, 89, 115-123. [CrossRef] [PubMed]

12. Bauman, Y.; Nachmani, D.; Vitenshtein, A.; Tsukerman, P.; Drayman, N.; Stern-Ginossar, N.; Lankry, D.; Gruda, R.; Mandelboim, $\mathrm{O}$. An identical miRNA of the human JC and BK polyoma viruses targets the stress-induced ligand ULBP3 to escape immune elimination. Cell Host Microbe 2011, 9, 93-102. [CrossRef]

13. Ribeiro, A.; Wornle, M.; Motamedi, N.; Anders, H.J.; Grone, E.F.; Nitschko, H.; Kurktschiev, P.; Debiec, H.; Kretzler, M.; Cohen, C.D.; et al. Activation of innate immune defense mechanisms contributes to polyomavirus BK-associated nephropathy. Kidney Int. 2012, 81, 100-111. [CrossRef]

14. Ginevri, F.; De Santis, R.; Comoli, P.; Pastorino, N.; Rossi, C.; Botti, G.; Fontana, I.; Nocera, A.; Cardillo, M.; Ciardi, M.R.; et al. Polyomavirus BK infection in pediatric kidney-allograft recipients: A single-center analysis of incidence, risk factors, and novel therapeutic approaches. Transplantation 2003, 75, 1266-1270. [CrossRef] [PubMed]

15. Smith, J.M.; McDonald, R.A.; Finn, L.S.; Healey, P.J.; Davis, C.L.; Limaye, A.P. Polyomavirus nephropathy in pediatric kidney transplant recipients. Am. J. Transplant. 2004, 4, 2109-2117. [CrossRef] [PubMed]

16. Wunderink, H.F.; van der Meijden, E.; van der Blij-de Brouwer, C.S.; Mallat, M.J.; Haasnoot, G.W.; van Zwet, E.W.; Claas, E.C.; de Fijter, J.W.; Kroes, A.C.; Arnold, F.; et al. Pretransplantation Donor-Recipient Pair Seroreactivity Against BK Polyomavirus Predicts Viremia and Nephropathy After Kidney Transplantation. Am. J. Transplant. 2017, 17, 161-172. [CrossRef] [PubMed] 
17. Bohl, D.L.; Storch, G.A.; Ryschkewitsch, C.; Gaudreault-Keener, M.; Schnitzler, M.A.; Major, E.O.; Brennan, D.C. Donor origin of BK virus in renal transplantation and role of HLA C7 in susceptibility to sustained BK viremia. Am. J. Transplant. 2005, 5, 2213-2221. [CrossRef]

18. Sood, P.; Senanayake, S.; Sujeet, K.; Medipalli, R.; Van-Why, S.K.; Cronin, D.C.; Johnson, C.P.; Hariharan, S. Donor and recipient BKV-specific IgG antibody and posttransplantation BKV infection: A prospective single-center study. Transplantation 2013, 95, 896-902. [CrossRef] [PubMed]

19. Abend, J.R.; Changala, M.; Sathe, A.; Casey, F.; Kistler, A.; Chandran, S.; Howard, A.; Wojciechowski, D. Correlation of BK Virus Neutralizing Serostatus With the Incidence of BK Viremia in Kidney Transplant Recipients. Transplantation 2017, 101, 1495-1505. [CrossRef] [PubMed]

20. Andrews, C.A.; Shah, K.V.; Daniel, R.W.; Hirsch, M.S.; Rubin, R.H. A serological investigation of BK virus and JC virus infections in recipients of renal allografts. J. Infect. Dis. 1988, 158, 176-181. [CrossRef]

21. Lamarche, C.; Orio, J.; Collette, S.; Senecal, L.; Hebert, M.J.; Renoult, E.; Tibbles, L.A.; Delisle, J.S. BK Polyomavirus and the Transplanted Kidney: Immunopathology and Therapeutic Approaches. Transplantation 2016, 100, 2276-2287. [CrossRef] [PubMed]

22. Li, C.; Diprimio, N.; Bowles, D.E.; Hirsch, M.L.; Monahan, P.E.; Asokan, A.; Rabinowitz, J.; Agbandje-McKenna, M.; Samulski, R.J. Single amino acid modification of adeno-associated virus capsid changes transduction and humoral immune profiles. J. Virol. 2012, 86, 7752-7759. [CrossRef]

23. Ciarlet, M.; Hoshino, Y.; Liprandi, F. Single point mutations may affect the serotype reactivity of serotype G11 porcine rotavirus strains: A widening spectrum? J. Virol. 1997, 71, 8213-8220. [CrossRef]

24. Renner, F.C.; Dietrich, H.; Bulut, N.; Celik, D.; Freitag, E.; Gaertner, N.; Karoui, S.; Mark, J.; Raatz, C.; Weimer, R.; et al. The risk of polyomavirus-associated graft nephropathy is increased by a combined suppression of CD8 and CD4 cell-dependent immune effects. Transplant. Proc. 2013, 45, 1608-1610. [CrossRef] [PubMed]

25. Schaenman, J.M.; Korin, Y.; Sidwell, T.; Kandarian, F.; Harre, N.; Gjertson, D.; Lum, E.L.; Reddy, U.; Huang, E.; Pham, P.T.; et al. Increased Frequency of BK Virus-Specific Polyfunctional CD8+ T Cells Predict Successful Control of BK Viremia After Kidney Transplantation. Transplantation 2017, 101, 1479-1487. [CrossRef]

26. Comoli, P.; Azzi, A.; Maccario, R.; Basso, S.; Botti, G.; Basile, G.; Fontana, I.; Labirio, M.; Cometa, A.; Poli, F.; et al. Polyomavirus BK-specific immunity after kidney transplantation. Transplantation 2004, 78, 1229-1232. [CrossRef]

27. Schachtner, T.; Stein, M.; Sefrin, A.; Babel, N.; Reinke, P. Inflammatory activation and recovering BKV-specific immunity correlate with self-limited BKV replication after renal transplantation. Transpl. Int. 2014, 27, 290-301. [CrossRef]

28. Schachtner, T.; Muller, K.; Stein, M.; Diezemann, C.; Sefrin, A.; Babel, N.; Reinke, P. BK virus-specific immunity kinetics: A predictor of recovery from polyomavirus BK-associated nephropathy. Am. J. Transplant. 2011, 11, 2443-2452. [CrossRef]

29. Comoli, P.; Hirsch, H.H.; Ginevri, F. Cellular immune responses to BK virus. Curr. Opin. Organ. Transplant. 2008, 13, 569-574. [CrossRef] [PubMed]

30. Schachtner, T.; Stein, M.; Babel, N.; Reinke, P. The Loss of BKV-specific Immunity From Pretransplantation to Posttransplantation Identifies Kidney Transplant Recipients at Increased Risk of BKV Replication. Am. J. Transplant. 2015, 15, 2159-2169. [CrossRef]

31. Ozsancak, C.; Auzou, P.; Dujardin, K.; Quinn, N.; Destee, A. Orofacial apraxia in corticobasal degeneration, progressive supranuclear palsy, multiple system atrophy and Parkinson's disease. J. Neurol 2004, 251, 1317-1323. [CrossRef]

32. Stolt, A.; Sasnauskas, K.; Koskela, P.; Lehtinen, M.; Dillner, J. Seroepidemiology of the human polyomaviruses. J. Gen. Virol 2003, 84 Pt 6, 1499-1504. [CrossRef]

33. Egli, A.; Infanti, L.; Dumoulin, A.; Buser, A.; Samaridis, J.; Stebler, C.; Gosert, R.; Hirsch, H.H. Prevalence of polyomavirus BK and JC infection and replication in 400 healthy blood donors. J. Infect. Dis. 2009, 199, 837-846. [CrossRef] [PubMed]

34. Virgin, H.W.; Wherry, E.J.; Ahmed, R. Redefining chronic viral infection. Cell 2009, 138, 30-50. [CrossRef]

35. Peinemann, F.; de Villiers, E.M.; Dorries, K.; Adams, O.; Vogeli, T.A.; Burdach, S. Clinical course and treatment of haemorrhagic cystitis associated with BK type of human polyomavirus in nine paediatric recipients of allogeneic bone marrow transplants. Eur. J. Pediatr. 2000, 159, 182-188. [CrossRef] [PubMed]

36. Low, J.; Humes, H.D.; Szczypka, M.; Imperiale, M. BKV and SV40 infection of human kidney tubular epithelial cells in vitro. Virology 2004, 323, 182-188. [CrossRef]

37. Koukoulaki, M.; Grispou, E.; Pistolas, D.; Balaska, K.; Apostolou, T.; Anagnostopoulou, M.; Tseleni-Kotsovili, A.; Hadjiconstantinou, V.; Paniara, O.; Saroglou, G.; et al. Prospective monitoring of BK virus replication in renal transplant recipients. Transpl Infect. Dis. 2009, 11, 1-10. [CrossRef] [PubMed]

38. Thakur, R.; Arora, S.; Nada, R.; Minz, M.; Joshi, K. Prospective monitoring of BK virus reactivation in renal transplant recipients in North India. Transpl Infect. Dis. 2011, 13, 575-583. [CrossRef]

39. Hirsch, H.H.; Knowles, W.; Dickenmann, M.; Passweg, J.; Klimkait, T.; Mihatsch, M.J.; Steiger, J. Prospective study of polyomavirus type BK replication and nephropathy in renal-transplant recipients. N. Engl. J. Med. 2002, 347, 488-496. [CrossRef]

40. Brennan, D.C.; Agha, I.; Bohl, D.L.; Schnitzler, M.A.; Hardinger, K.L.; Lockwood, M.; Torrence, S.; Schuessler, R.; Roby, T.; Gaudreault-Keener, M.; et al. Incidence of BK with tacrolimus versus cyclosporine and impact of preemptive immunosuppression reduction. Am. J. Transplant. 2005, 5, 582-594. [CrossRef] [PubMed] 
41. Schwarz, A.; Linnenweber-Held, S.; Heim, A.; Framke, T.; Haller, H.; Schmitt, C. Viral Origin, Clinical Course, and Renal Outcomes in Patients With BK Virus Infection After Living-Donor Renal Transplantation. Transplantation 2016, 100, 844-853. [CrossRef]

42. Kahan, A.V.; Coleman, D.V.; Koss, L.G. Activation of human polyomavirus infection-detection by cytologic technics. Am. J. Clin. Pathol. 1980, 74, 326-332. [CrossRef] [PubMed]

43. Nickeleit, V.; Singh, H.K.; Randhawa, P.; Drachenberg, C.B.; Bhatnagar, R.; Bracamonte, E.; Chang, A.; Chon, W.J.; Dadhania, D.; Davis, V.G.; et al. The Banff Working Group Classification of Definitive Polyomavirus Nephropathy: Morphologic Definitions and Clinical Correlations. J. Am. Soc. Nephrol. 2018, 29, 680-693. [CrossRef]

44. Hirsch, H.H. Polyomavirus BK nephropathy: A (re-)emerging complication in renal transplantation. Am. J. Transplant. 2002, 2, 25-30. [CrossRef] [PubMed]

45. Randhawa, P.S.; Demetris, A.J. Nephropathy due to polyomavirus type BK. N. Engl. J. Med. 2000, 342, 1361-1363. [CrossRef] [PubMed]

46. Costa, J.S.; Ferreira, E.; Leal, R.; Bota, N.; Romaozinho, C.; Sousa, V.; Marinho, C.; Santos, L.; Macario, F.; Alves, R.; et al. Polyomavirus Nephropathy: Ten-Year Experience. Transplant. Proc. 2017, 49, 803-808. [CrossRef]

47. Hirsch, H.H.; Vincenti, F.; Friman, S.; Tuncer, M.; Citterio, F.; Wiecek, A.; Scheuermann, E.H.; Klinger, M.; Russ, G.; Pescovitz, M.D.; et al. Polyomavirus BK replication in de novo kidney transplant patients receiving tacrolimus or cyclosporine: A prospective, randomized, multicenter study. Am. J. Transplant. 2013, 13, 136-145. [CrossRef]

48. Schaub, S.; Hirsch, H.H.; Dickenmann, M.; Steiger, J.; Mihatsch, M.J.; Hopfer, H.; Mayr, M. Reducing immunosuppression preserves allograft function in presumptive and definitive polyomavirus-associated nephropathy. Am. J. Transplant. 2010, 10, 2615-2623. [CrossRef] [PubMed]

49. Viscount, H.B.; Eid, A.J.; Espy, M.J.; Griffin, M.D.; Thomsen, K.M.; Harmsen, W.S.; Razonable, R.R.; Smith, T.F. Polyomavirus polymerase chain reaction as a surrogate marker of polyomavirus-associated nephropathy. Transplantation 2007, 84, 340-345. [CrossRef] [PubMed]

50. Hirsch, H.H.; Randhawa, P.S.; on behalf of AST Infectious Diseases Community of Practice. BK polyomavirus in solid organ transplantation-Guidelines from the American Society of Transplantation Infectious Diseases Community of Practice. Clin. Transplant. 2019, 33, e13528. [CrossRef]

51. Yamada, Y.; Tsuchiya, T.; Inagaki, I.; Seishima, M.; Deguchi, T. Prediction of Early BK Virus Infection in Kidney Transplant Recipients by the Number of Cells With Intranuclear Inclusion Bodies (Decoy Cells). Transplant. Direct. 2018, 4, e340. [CrossRef]

52. Kidney Disease: Improving Global Outcomes Transplant Work Group. KDIGO clinical practice guideline for the care of kidney transplant recipients. Am. J. Transplant. 2009, 9 (Suppl. 3), S1-S155. [CrossRef]

53. Sawinski, D.; Goral, S. BK virus infection: An update on diagnosis and treatment. Nephrol Dial. Transplant. 2015, 30, $209-217$. [CrossRef]

54. Drachenberg, C.B.; Beskow, C.O.; Cangro, C.B.; Bourquin, P.M.; Simsir, A.; Fink, J.; Weir, M.R.; Klassen, D.K.; Bartlett, S.T.; Papadimitriou, J.C. Human polyoma virus in renal allograft biopsies: Morphological findings and correlation with urine cytology. Hum. Pathol. 1999, 30, 970-977. [CrossRef]

55. Nankivell, B.J.; Renthawa, J.; Sharma, R.N.; Kable, K.; O'Connell, P.J.; Chapman, J.R. BK Virus Nephropathy: Histological Evolution by Sequential Pathology. Am. J. Transplant. 2017, 17, 2065-2077. [CrossRef]

56. Hirsch, H.H.; Randhawa, P.; the AST Infectious Diseases Community of Practice. BK polyomavirus in solid organ transplantation. Am. J. Transplant. 2013, 13 (Suppl. 4), 179-188. [CrossRef] [PubMed]

57. Bracamonte, E.; Leca, N.; Smith, K.D.; Nicosia, R.F.; Nickeleit, V.; Kendrick, E.; Furmanczyk, P.S.; Davis, C.L.; Alpers, C.E.; Kowalewska, J. Tubular basement membrane immune deposits in association with BK polyomavirus nephropathy. Am. J. Transplant. 2007, 7, 1552-1560. [CrossRef]

58. Hever, A.; Nast, C.C. Polyoma virus nephropathy with simian virus 40 antigen-containing tubular basement membrane immune complex deposition. Hum. Pathol. 2008, 39, 73-79. [CrossRef]

59. McGregor, S.M.; Chon, W.J.; Kim, L.; Chang, A.; Meehan, S.M. Clinical and pathological features of kidney transplant patients with concurrent polyomavirus nephropathy and rejection-associated endarteritis. World J. Transplant. 2015, 5, 292-299. [CrossRef] [PubMed]

60. Reploeg, M.D.; Storch, G.A.; Clifford, D.B. Bk virus: A clinical review. Clin. Infect. Dis. 2001, 33, 191-202. [CrossRef] [PubMed]

61. Bohl, D.L.; Brennan, D.C. BK virus nephropathy and kidney transplantation. Clin. J. Am. Soc. Nephrol. 2007, 2 (Suppl. 1), S36-S46. [CrossRef]

62. Dharnidharka, V.R.; Cherikh, W.S.; Abbott, K.C. An OPTN analysis of national registry data on treatment of BK virus allograft nephropathy in the United States. Transplantation 2009, 87, 1019-1026. [CrossRef]

63. Shenagari, M.; Monfared, A.; Eghtedari, H.; Pourkazemi, A.; Hasandokht, T.; Khosravi, M.; Asharfkhani, B. BK virus replication in renal transplant recipients: Analysis of potential risk factors may contribute in reactivation. J. Clin. Virol. 2017, 96, 7-11. [CrossRef]

64. Schold, J.D.; Rehman, S.; Kayle, L.K.; Magliocca, J.; Srinivas, T.R.; Meier-Kriesche, H.U. Treatment for BK virus: Incidence, risk factors and outcomes for kidney transplant recipients in the United States. Transpl. Int. 2009, 22, 626-634. [CrossRef] 
65. Sharif, A.; Alachkar, N.; Bagnasco, S.; Geetha, D.; Gupta, G.; Womer, K.; Arend, L.; Racusen, L.; Montgomery, R.; Kraus, E. Incidence and outcomes of BK virus allograft nephropathy among ABO- and HLA-incompatible kidney transplant recipients. Clin. J. Am. Soc. Nephrol. 2012, 7, 1320-1327. [CrossRef]

66. Borni-Duval, C.; Caillard, S.; Olagne, J.; Perrin, P.; Braun-Parvez, L.; Heibel, F.; Moulin, B. Risk factors for BK virus infection in the era of therapeutic drug monitoring. Transplantation 2013, 95, 1498-1505. [CrossRef] [PubMed]

67. Shen, C.L.; Yang, A.H.; Lien, T.J.; Tarng, D.C.; Yang, C.Y. Tacrolimus Blood Level Fluctuation Predisposes to Coexisting BK Virus Nephropathy and Acute Allograft Rejection. Sci. Rep. 2017, 7, 1986. [CrossRef]

68. Kim, H.; Yu, H.; Baek, C.H.; Han, D.J.; Park, S.K. High-dose steroid therapy in BK viremia adversely affected the long-term graft function after kidney transplantation. Transpl Infect. Dis 2016, 18, 844-849. [CrossRef] [PubMed]

69. Pai, D.; Mann, D.M.; Malik, A.; Hoover, D.R.; Fyfe, B.; Mann, R.A. Risk Factors for the Development of BK Virus Nephropathy in Renal Transplant Recipients. Transplant. Proc. 2015, 47, 2465-2469. [CrossRef]

70. Thomas, A.; Dropulic, L.K.; Rahman, M.H.; Geetha, D. Ureteral stents: A novel risk factor for polyomavirus nephropathy. Transplantation 2007, 84, 433-436. [CrossRef] [PubMed]

71. Kayler, L.; Zendejas, I.; Schain, D.; Magliocca, J. Ureteral stent placement and BK viremia in kidney transplant recipients. Transpl. Infect. Dis 2013, 15, 202-207. [CrossRef] [PubMed]

72. Manitpisitkul, W.; Wilson, N.S.; Haririan, A. Immunosuppressive agents as risk factors for BK virus nephropathy: An overview and update. Expert Opin. Drug Saf. 2010, 9, 959-969. [CrossRef] [PubMed]

73. Demey, B.; Tinez, C.; Francois, C.; Helle, F.; Choukroun, G.; Duverlie, G.; Castelain, S.; Brochot, E. Risk factors for BK virus viremia and nephropathy after kidney transplantation: A systematic review. J. Clin. Virol. 2018, 109, 6-12. [CrossRef]

74. Prince, O.; Savic, S.; Dickenmann, M.; Steiger, J.; Bubendorf, L.; Mihatsch, M.J. Risk factors for polyoma virus nephropathy. Nephrol. Dial. Transplant. 2009, 24, 1024-1033. [CrossRef] [PubMed]

75. Pirsch, J.D.; Miller, J.; Deierhoi, M.H.; Vincenti, F.; Filo, R.S. A comparison of tacrolimus (FK506) and cyclosporine for immunosuppression after cadaveric renal transplantation. FK506 Kidney Transplant Study Group. Transplantation 1997, 63, 977-983. [CrossRef]

76. Webster, A.C.; Woodroffe, R.C.; Taylor, R.S.; Chapman, J.R.; Craig, J.C. Tacrolimus versus ciclosporin as primary immunosuppression for kidney transplant recipients: Meta-analysis and meta-regression of randomised trial data. BMJ 2005, 331, 810. [CrossRef] [PubMed]

77. Benavides, C.A.; Pollard, V.B.; Mauiyyedi, S.; Podder, H.; Knight, R.; Kahan, B.D. BK virus-associated nephropathy in sirolimustreated renal transplant patients: Incidence, course, and clinical outcomes. Transplantation 2007, 84, 83-88. [CrossRef] [PubMed]

78. Leng, T.; Lin, J.; Cottrell, J.E.; Xiong, Z.G. Subunit and frequency-dependent inhibition of acid sensing ion channels by local anesthetic tetracaine. Mol. Pain 2013, 9, 27. [CrossRef]

79. Hirsch, H.H.; Yakhontova, K.; Lu, M.; Manzetti, J. BK Polyomavirus Replication in Renal Tubular Epithelial Cells Is Inhibited by Sirolimus, but Activated by Tacrolimus Through a Pathway Involving FKBP-12. Am. J. Transplant. 2016, 16, 821-832. [CrossRef]

80. Solis, M.; Velay, A.; Porcher, R.; Domingo-Calap, P.; Soulier, E.; Joly, M.; Meddeb, M.; Kack-Kack, W.; Moulin, B.; Bahram, S.; et al. Neutralizing Antibody-Mediated Response and Risk of BK Virus-Associated Nephropathy. J. Am. Soc. Nephrol. 2018, $29,326-334$. [CrossRef]

81. Dakroub, F.; Touze, A.; Akl, H.; Brochot, E. Pre-Transplantation Assessment of BK Virus Serostatus: Significance, Current Methods, and Obstacles. Viruses 2019, 11, 945. [CrossRef] [PubMed]

82. Matas, A.J.; Smith, J.M.; Skeans, M.A.; Lamb, K.E.; Gustafson, S.K.; Samana, C.J.; Stewart, D.E.; Snyder, J.J.; Israni, A.K.; Kasiske, B.L. OPTN/SRTR 2011 Annual Data Report: Kidney. Am. J. Transplant. 2013, 13 (Suppl. 1), 11-46. [CrossRef]

83. Lamb, K.E.; Lodhi, S.; Meier-Kriesche, H.U. Long-term renal allograft survival in the United States: A critical reappraisal. Am. J. Transplant. 2011, 11, 450-462. [CrossRef]

84. van Gelder, T. Within-patient variability in immunosuppressive drug exposure as a predictor for poor outcome after transplantation. Kidney Int. 2014, 85, 1267-1268. [CrossRef]

85. Shuker, N.; van Gelder, T.; Hesselink, D.A. Intra-patient variability in tacrolimus exposure: Causes, consequences for clinical management. Transplant. Rev. 2015, 29, 78-84. [CrossRef] [PubMed]

86. Arreola-Guerra, J.M.; Serrano, M.; Morales-Buenrostro, L.E.; Vilatoba, M.; Alberu, J. Tacrolimus Trough Levels as a Risk Factor for Acute Rejection in Renal Transplant Patients. Ann. Transplant. 2016, 21, 105-114. [CrossRef] [PubMed]

87. Israni, A.K.; Riad, S.M.; Leduc, R.; Oetting, W.S.; Guan, W.; Schladt, D.; Matas, A.J.; Jacobson, P.A.; De, K.A.F.G.I. Tacrolimus trough levels after month 3 as a predictor of acute rejection following kidney transplantation: A lesson learned from DeKAF Genomics. Transpl. Int. 2013, 26, 982-989. [CrossRef]

88. Gaynor, J.J.; Ciancio, G.; Guerra, G.; Sageshima, J.; Roth, D.; Goldstein, M.J.; Chen, L.; Kupin, W.; Mattiazzi, A.; Tueros, L.; et al. Lower tacrolimus trough levels are associated with subsequently higher acute rejection risk during the first 12 months after kidney transplantation. Transpl. Int. 2016, 29, 216-226. [CrossRef] [PubMed]

89. Akturk, S.; Erdogmus, S.; Kumru, G.; Elhan, A.H.; Sengul, S.; Tuzuner, A.; Keven, K. Average Tacrolimus Trough Level in the First Month After Transplantation May Predict Acute Rejection. Transplant. Proc. 2017, 49, 430-435. [CrossRef]

90. Schiff, J.; Cole, E.; Cantarovich, M. Therapeutic monitoring of calcineurin inhibitors for the nephrologist. Clin. J. Am. Soc. Nephrol. 2007, 2, 374-384. [CrossRef] [PubMed] 
91. Murphy, G.J.; Waller, J.R.; Sandford, R.S.; Furness, P.N.; Nicholson, M.L. Randomized clinical trial of the effect of microemulsion cyclosporin and tacrolimus on renal allograft fibrosis. Br. J. Surg. 2003, 90, 680-686. [CrossRef] [PubMed]

92. Yin, S.; Song, T.; Li, X.; Xu, H.; Zhang, X.; Jiang, Y.; Lin, T. Non-linear Relationship between Tacrolimus Blood Concentration and Acute Rejection After Kidney Transplantation: A Systematic Review and Dose-Response Meta-Analysis of Cohort Studies. Curr. Pharm. Des. 2019, 25, 2394-2403. [CrossRef]

93. Anglicheau, D.; Legendre, C.; Thervet, E. Pharmacogenetics of tacrolimus and sirolimus in renal transplant patients: From retrospective analyses to prospective studies. Transplant. Proc. 2007, 39, 2142-2144. [CrossRef] [PubMed]

94. van den Hoogen, M.; Hilbrands, L. Reduced exposure to calcineurin inhibitors in renal transplantation. N. Engl. J. Med. 2008, 358, 2519-2520.

95. Staatz, C.E.; Tett, S.E. Clinical pharmacokinetics and pharmacodynamics of tacrolimus in solid organ transplantation. Clin. Pharmacokinet 2004, 43, 623-653. [CrossRef] [PubMed]

96. Shishido, S.; Asanuma, H.; Tajima, E.; Honda, M.; Nakai, H. Pharmacokinetics of tacrolimus in pediatric renal transplant recipients. Transplant. Proc. 2001, 33, 1066-1068. [CrossRef]

97. Fruhwirth, M.; Fischer, H.; Simma, B.; Hochleitner, B.; Konigsrainer, A.; Margreiter, R.; Ellemunter, H. Rotavirus infection as cause of tacrolimus elevation in solid-organ-transplanted children. Pediatr Transplant. 2001, 5, 88-92. [CrossRef]

98. Felipe, C.R.; Garcia, C.; Moreira, S.; Olsen, N.; Silva, H.T.; Pestana, O.M. Choosing the right dose of new immunossuppressive drugs for new populations: Importance of pharmacokinetic studies. Transplant. Proc. 2001, 33, 1095-1096. [CrossRef]

99. Mancinelli, L.M.; Frassetto, L.; Floren, L.C.; Dressler, D.; Carrier, S.; Bekersky, I.; Benet, L.Z.; Christians, U. The pharmacokinetics and metabolic disposition of tacrolimus: A comparison across ethnic groups. Clin. Pharmacol Ther. 2001, 69, 24-31. [CrossRef] [PubMed]

100. Felipe, C.R.; Silva, H.T.; Machado, P.G.; Garcia, R.; da Silva Moreira, S.R.; Pestana, J.O. The impact of ethnic miscegenation on tacrolimus clinical pharmacokinetics and therapeutic drug monitoring. Clin. Transplant. 2002, 16, 262-272. [CrossRef]

101. Undre, N.A.; Schafer, A. Factors affecting the pharmacokinetics of tacrolimus in the first year after renal transplantation. European Tacrolimus Multicentre Renal Study Group. Transplant. Proc. 1998, 30, 1261-1263. [CrossRef]

102. Satoh, S.; Tada, H.; Tachiki, Y.; Tsuchiya, N.; Shimoda, N.; Akao, T.; Sato, K.; Habuchi, T.; Suzuki, T.; Kato, T. Chrono and clinical pharmacokinetic study of tacrolimus in continuous intravenous administration. Int. J. Urol. 2001, 8, 353-358. [CrossRef] [PubMed]

103. Giordano, G.; D’Adda, T.; Gnetti, L.; Froio, E.; Merisio, C.; Melpignano, M. Detection of human papillomavirus in organs of upper genital tract in women with cervical cancer. Int. J. Gynecol. Cancer 2006, 16, 1601-1607. [CrossRef] [PubMed]

104. Kuypers, D.R.J. Intrapatient Variability of Tacrolimus Exposure in Solid Organ Transplantation: A Novel Marker for Clinical Outcome. Clin. Pharmacol. Ther. 2020, 107, 347-358. [CrossRef] [PubMed]

105. Butler, J.A.; Roderick, P.; Mullee, M.; Mason, J.C.; Peveler, R.C. Frequency and impact of nonadherence to immunosuppressants after renal transplantation: A systematic review. Transplantation 2004, 77, 769-776. [CrossRef]

106. Christians, U.; Jacobsen, W.; Benet, L.Z.; Lampen, A. Mechanisms of clinically relevant drug interactions associated with tacrolimus. Clin. Pharm. 2002, 41, 813-851. [CrossRef]

107. Liu, C.; Shang, Y.F.; Zhang, X.F.; Zhang, X.G.; Wang, B.; Wu, Z.; Liu, X.M.; Yu, L.; Ma, F.; Lv, Y. Co-administration of grapefruit juice increases bioavailability of tacrolimus in liver transplant patients: A prospective study. Eur. J. Clin. Pharmacol. 2009, 65, 881-885. [CrossRef] [PubMed]

108. Egashira, K.; Fukuda, E.; Onga, T.; Yogi, Y.; Matsuya, F.; Koyabu, N.; Ohtani, H.; Sawada, Y. Pomelo-induced increase in the blood level of tacrolimus in a renal transplant patient. Transplantation 2003, 75, 1057. [CrossRef]

109. Bekersky, I.; Dressler, D.; Mekki, Q. Effect of time of meal consumption on bioavailability of a single oral $5 \mathrm{mg}$ tacrolimus dose. J. Clin. Pharmacol. 2001, 41, 289-297. [CrossRef]

110. Bekersky, I.; Dressler, D.; Mekki, Q.A. Effect of low- and high-fat meals on tacrolimus absorption following $5 \mathrm{mg}$ single oral doses to healthy human subjects. J. Clin. Pharmacol. 2001, 41, 176-182. [CrossRef] [PubMed]

111. Vanhove, T.; Annaert, P.; Kuypers, D.R. Clinical determinants of calcineurin inhibitor disposition: A mechanistic review. Drug Metab Rev. 2016, 48, 88-112. [CrossRef]

112. Staatz, C.E.; Goodman, L.K.; Tett, S.E. Effect of CYP3A and ABCB1 single nucleotide polymorphisms on the pharmacokinetics and pharmacodynamics of calcineurin inhibitors: Part I. Clin. Pharm. 2010, 49, 141-175. [CrossRef] [PubMed]

113. Borra, L.C.; Roodnat, J.I.; Kal, J.A.; Mathot, R.A.; Weimar, W.; van Gelder, T. High within-patient variability in the clearance of tacrolimus is a risk factor for poor long-term outcome after kidney transplantation. Nephrol Dial. Transplant. 2010, 25, $2757-2763$. [CrossRef]

114. Shuker, N.; Shuker, L.; van Rosmalen, J.; Roodnat, J.I.; Borra, L.C.; Weimar, W.; Hesselink, D.A.; van Gelder, T. A high intrapatient variability in tacrolimus exposure is associated with poor long-term outcome of kidney transplantation. Transpl. Int. 2016, 29, 1158-1167. [CrossRef]

115. Rozen-Zvi, B.; Schneider, S.; Lichtenberg, S.; Green, H.; Cohen, O.; Gafter, U.; Chagnac, A.; Mor, E.; Rahamimov, R. Association of the combination of time-weighted variability of tacrolimus blood level and exposure to low drug levels with graft survival after kidney transplantation. Nephrol. Dial. Transplant. 2017, 32, 393-399. [CrossRef] [PubMed]

116. Ro, H.; Min, S.I.; Yang, J.; Moon, K.C.; Kim, Y.S.; Kim, S.J.; Ahn, C.; Ha, J. Impact of tacrolimus intraindividual variability and CYP3A5 genetic polymorphism on acute rejection in kidney transplantation. Ther. Drug Monit. 2012, 34, 680-685. [CrossRef] 
117. Sapir-Pichhadze, R.; Wang, Y.; Famure, O.; Li, Y.; Kim, S.J. Time-dependent variability in tacrolimus trough blood levels is a risk factor for late kidney transplant failure. Kidney Int. 2014, 85, 1404-1411. [CrossRef]

118. Rodrigo, E.; Segundo, D.S.; Fernandez-Fresnedo, G.; Lopez-Hoyos, M.; Benito, A.; Ruiz, J.C.; de Cos, M.A.; Arias, M. WithinPatient Variability in Tacrolimus Blood Levels Predicts Kidney Graft Loss and Donor-Specific Antibody Development. Transplantation 2016, 100, 2479-2485. [CrossRef]

119. Sablik, K.A.; Clahsen-van Groningen, M.C.; Hesselink, D.A.; van Gelder, T.; Betjes, M.G.H. Tacrolimus intra-patient variability is not associated with chronic active antibody mediated rejection. PLoS ONE 2018, 13, e0196552. [CrossRef]

120. Vanhove, T.; Vermeulen, T.; Annaert, P.; Lerut, E.; Kuypers, D.R.J. High Intrapatient Variability of Tacrolimus Concentrations Predicts Accelerated Progression of Chronic Histologic Lesions in Renal Recipients. Am. J. Transplant. 2016, 16, 2954-2963. [CrossRef]

121. Albano, L.; Banas, B.; Klempnauer, J.L.; Glyda, M.; Viklicky, O.; Kamar, N.; Optimising immunoSuppression After Kidney Transplantation with ADVAGRAF (OSAKA) Study Group. OSAKA trial: A randomized, controlled trial comparing tacrolimus QD and BD in kidney transplantation. Transplantation 2013, 96, 897-903. [CrossRef]

122. Han, D.J.; Park, J.B.; Kim, Y.S.; Kim, S.J.; Ha, J.; Kim, H.C.; Kim, S.J.; Moon, I.S.; Yang, C.W. A 39-month follow-up study to evaluate the safety and efficacy in kidney transplant recipients treated with modified-release tacrolimus (FK506E)-based immunosuppression regimen. Transplant. Proc. 2012, 44, 115-117. [CrossRef]

123. Kramer, B.K.; Charpentier, B.; Backman, L.; Silva, H.T., Jr.; Mondragon-Ramirez, G.; Cassuto-Viguier, E.; Mourad, G.; Sola, R.; Rigotti, P.; Mirete, J.O.; et al. Tacrolimus once daily (ADVAGRAF) versus twice daily (PROGRAF) in de novo renal transplantation: A randomized phase III study. Am. J. Transplant. 2010, 10, 2632-2643. [CrossRef]

124. Silva, H.T., Jr.; Yang, H.C.; Abouljoud, M.; Kuo, P.C.; Wisemandle, K.; Bhattacharya, P.; Dhadda, S.; Holman, J.; Fitzsimmons, W.; First, M.R. One-year results with extended-release tacrolimus/MMF, tacrolimus/MMF and cyclosporine/MMF in de novo kidney transplant recipients. Am. J. Transplant. 2007, 7, 595-608. [CrossRef] [PubMed]

125. Kuypers, D.R.; Peeters, P.C.; Sennesael, J.J.; Kianda, M.N.; Vrijens, B.; Kristanto, P.; Dobbels, F.; Vanrenterghem, Y.; Kanaan, N.; Team, A.S. Improved adherence to tacrolimus once-daily formulation in renal recipients: A randomized controlled trial using electronic monitoring. Transplantation 2013, 95, 333-340. [CrossRef] [PubMed]

126. Wu, M.J.; Cheng, C.Y.; Chen, C.H.; Wu, W.P.; Cheng, C.H.; Yu, D.M.; Chuang, Y.W.; Shu, K.H. Lower variability of tacrolimus trough concentration after conversion from prograf to advagraf in stable kidney transplant recipients. Transplantation 2011, 92, 648-652. [CrossRef]

127. McGillicuddy, J.W.; Chandler, J.L.; Sox, L.R.; Taber, D.J. Exploratory Analysis of the Impact of an mHealth Medication Adherence Intervention on Tacrolimus Trough Concentration Variability: Post Hoc Results of a Randomized Controlled Trial. Ann. Pharmacother. 2020, 54, 1185-1193. [CrossRef]

128. Gonzales, H.M.; McGillicuddy, J.W.; Rohan, V.; Chandler, J.L.; Nadig, S.N.; Dubay, D.A.; Taber, D.J. A comprehensive review of the impact of tacrolimus intrapatient variability on clinical outcomes in kidney transplantation. Am. J. Transplant. 2020, 20, 1969-1983. [CrossRef]

129. Ueda, A.; Wasa, H.; Suzuki, S.; Okada, K.; Sato, K.; Takui, T.; Morita, Y. Chiral stable phenalenyl radical: Synthesis, electronic-spin structure, and optical properties of [4]helicene-structured diazaphenalenyl. Angew. Chem. Int. Ed. Engl. 2012, 51, 6691-6695. [CrossRef] [PubMed]

130. Thangaraju, S.; Gill, J.; Wright, A.; Dong, J.; Rose, C.; Gill, J. Risk Factors for BK Polyoma Virus Treatment and Association of Treatment With Kidney Transplant Failure: Insights From a Paired Kidney Analysis. Transplantation 2016, 100, 854-861. [CrossRef]

131. Bussalino, E.; Marsano, L.; Parodi, A.; Russo, R.; Massarino, F.; Ravera, M.; Gaggero, G.; Fontana, I.; Garibotto, G.; Zaza, G.; et al. Everolimus for BKV nephropathy in kidney transplant recipients: A prospective, controlled study. J. Nephrol. 2020. [CrossRef]

132. Suwelack, B.; Malyar, V.; Koch, M.; Sester, M.; Sommerer, C. The influence of immunosuppressive agents on BK virus risk following kidney transplantation, and implications for choice of regimen. Transplant. Rev. 2012, 26, 201-211. [CrossRef]

133. Wehmeier, C.; Honger, G.; Cun, H.; Amico, P.; Hirt-Minkowski, P.; Georgalis, A.; Hopfer, H.; Dickenmann, M.; Steiger, J.; Schaub, S. Donor Specificity but Not Broadness of Sensitization Is Associated With Antibody-Mediated Rejection and Graft Loss in Renal Allograft Recipients. Am. J. Transplant. 2017, 17, 2092-2102. [CrossRef]

134. Sawinski, D.; Trofe-Clark, J.; Leas, B.; Uhl, S.; Tuteja, S.; Kaczmarek, J.L.; French, B.; Umscheid, C.A. Calcineurin Inhibitor Minimization, Conversion, Withdrawal, and Avoidance Strategies in Renal Transplantation: A Systematic Review and MetaAnalysis. Am. J. Transplant. 2016, 16, 2117-2138. [CrossRef]

135. Davis, S.; Gralla, J.; Klem, P.; Tong, S.; Wedermyer, G.; Freed, B.; Wiseman, A.; Cooper, J.E. Lower tacrolimus exposure and time in therapeutic range increase the risk of de novo donor-specific antibodies in the first year of kidney transplantation. Am. $J$. Transplant. 2018, 18, 907-915. [CrossRef]

136. Kim, M.H.; Lee, Y.H.; Seo, J.W.; Moon, H.; Kim, J.S.; Kim, Y.G.; Jeong, K.H.; Moon, J.Y.; Lee, T.W.; Ihm, C.G.; et al. Urinary exosomal viral microRNA as a marker of BK virus nephropathy in kidney transplant recipients. PLoS ONE 2017, 12, e0190068. [CrossRef]

137. Tian, Y.C.; Li, Y.J.; Chen, H.C.; Wu, H.H.; Weng, C.H.; Chen, Y.C.; Lee, C.C.; Chang, M.Y.; Hsu, H.H.; Yen, T.H.; et al. Polyomavirus BK-encoded microRNA suppresses autoregulation of viral replication. Biochem. Biophys. Res. Commun 2014, 447, 543-549. [CrossRef] 
138. Li, J.Y.; McNicholas, K.; Yong, T.Y.; Rao, N.; Coates, P.T.; Higgins, G.D.; Carroll, R.P.; Woodman, R.J.; Michael, M.Z.; Gleadle, J.M. BK virus encoded microRNAs are present in blood of renal transplant recipients with BK viral nephropathy. Am. J. Transplant. 2014, 14, 1183-1190. [CrossRef] [PubMed]

139. Dvir, R.; Paloschi, V.; Canducci, F.; Dell'Antonio, G.; Racca, S.; Caldara, R.; Pantaleo, G.; Clementi, M.; Secchi, A. IL28B rs12979860 genotype as a predictor marker of progression to BKVirus Associated nephropathy, after kidney transplantation. Sci. Rep. 2017, 7, 6746. [CrossRef] [PubMed]

140. Ho, J.; Schaub, S.; Wiebe, C.; Gao, A.; Wehmeier, C.; Koller, M.T.; Hirsch, H.H.; Hopfer, H.; Nickerson, P.; Hirt-Minkowski, P. Urinary CXCL10 Chemokine Is Associated With Alloimmune and Virus Compartment-Specific Renal Allograft Inflammation. Transplantation 2018, 102, 521-529. [CrossRef]

141. Quaglia, M.; Merlotti, G.; Guglielmetti, G.; Castellano, G.; Cantaluppi, V. Recent Advances on Biomarkers of Early and Late Kidney Graft Dysfunction. Int. J. Mol. Sci. 2020, 21, 5404. [CrossRef] [PubMed]

142. Suthanthiran, M.; Schwartz, J.E.; Ding, R.; Abecassis, M.; Dadhania, D.; Samstein, B.; Knechtle, S.J.; Friedewald, J.; Becker, Y.T.; Sharma, V.K.; et al. Urinary-cell mRNA profile and acute cellular rejection in kidney allografts. N. Engl. J. Med. 2013, 369, 20-31. [CrossRef]

143. Rabant, M.; Amrouche, L.; Lebreton, X.; Aulagnon, F.; Benon, A.; Sauvaget, V.; Bonifay, R.; Morin, L.; Scemla, A.; Delville, M.; et al. Urinary C-X-C Motif Chemokine 10 Independently Improves the Noninvasive Diagnosis of Antibody-Mediated Kidney Allograft Rejection. J. Am. Soc. Nephrol. 2015, 26, 2840-2851. [CrossRef]

144. Hricik, D.E.; Nickerson, P.; Formica, R.N.; Poggio, E.D.; Rush, D.; Newell, K.A.; Goebel, J.; Gibson, I.W.; Fairchild, R.L.; Riggs, M.; et al. Multicenter validation of urinary CXCL9 as a risk-stratifying biomarker for kidney transplant injury. Am. J. Transplant. 2013, 13, 2634-2644. [CrossRef] [PubMed]

145. Jackson, J.A.; Kim, E.J.; Begley, B.; Cheeseman, J.; Harden, T.; Perez, S.D.; Thomas, S.; Warshaw, B.; Kirk, A.D. Urinary chemokines CXCL9 and CXCL10 are noninvasive markers of renal allograft rejection and BK viral infection. Am. J. Transplant. 2011, 11, 2228-2234. [CrossRef]

146. Schaub, S.; Nickerson, P.; Rush, D.; Mayr, M.; Hess, C.; Golian, M.; Stefura, W.; Hayglass, K. Urinary CXCL9 and CXCL10 levels correlate with the extent of subclinical tubulitis. Am. J. Transplant. 2009, 9, 1347-1353. [CrossRef] [PubMed]

147. Gielis, E.M.; Beirnaert, C.; Dendooven, A.; Meysman, P.; Laukens, K.; De Schrijver, J.; Van Laecke, S.; Van Biesen, W.; Emonds, M.P.; De Winter, B.Y.; et al. Plasma donor-derived cell-free DNA kinetics after kidney transplantation using a single tube multiplex PCR assay. PLoS ONE 2018, 13, e0208207. [CrossRef] [PubMed]

148. Yang, C.Y.; Shih, C.J.; Yang, W.C.; Lin, C.C. Aggressive immunosuppressant reduction and long-term rejection risk in renal transplant recipients with Pneumocystis jiroveci pneumonia. Exp. Clin. Transplant. 2012, 10, 344-349. [CrossRef]

149. Shih, C.J.; Tarng, D.C.; Yang, W.C.; Yang, C.Y. Immunosuppressant dose reduction and long-term rejection risk in renal transplant recipients with severe bacterial pneumonia. Singapore Med. J. 2014, 55, 372-377. [CrossRef]

150. Johnston, O.; Jaswal, D.; Gill, J.S.; Doucette, S.; Fergusson, D.A.; Knoll, G.A. Treatment of polyomavirus infection in kidney transplant recipients: A systematic review. Transplantation 2010, 89, 1057-1070. [CrossRef]

151. Sood, P.; Senanayake, S.; Sujeet, K.; Medipalli, R.; Zhu, Y.R.; Johnson, C.P.; Hariharan, S. Management and outcome of BK viremia in renal transplant recipients: A prospective single-center study. Transplantation 2012, 94, 814-821. [CrossRef]

152. Elfadawy, N.; Flechner, S.M.; Liu, X.; Schold, J.; Tian, D.; Srinivas, T.R.; Poggio, E.; Fatica, R.; Avery, R.; Mossad, S.B. The impact of surveillance and rapid reduction in immunosuppression to control BK virus-related graft injury in kidney transplantation. Transpl. Int. 2013, 26, 822-832. [CrossRef] [PubMed]

153. Sawinski, D.; Forde, K.A.; Trofe-Clark, J.; Patel, P.; Olivera, B.; Goral, S.; Bloom, R.D. Persistent BK viremia does not increase intermediate-term graft loss but is associated with de novo donor-specific antibodies. J. Am. Soc. Nephrol. 2015, 26, 966-975. [CrossRef]

154. Seifert, M.E.; Gunasekaran, M.; Horwedel, T.A.; Daloul, R.; Storch, G.A.; Mohanakumar, T.; Brennan, D.C. Polyomavirus Reactivation and Immune Responses to Kidney-Specific Self-Antigens in Transplantation. J. Am. Soc. Nephrol. 2017, 28, 1314-1325. [CrossRef] [PubMed]

155. Bischof, N.; Hirsch, H.H.; Wehmeier, C.; Amico, P.; Dickenmann, M.; Hirt-Minkowski, P.; Steiger, J.; Menter, T.; Helmut, H.; Schaub, S. Reducing calcineurin inhibitor first for treating BK polyomavirus replication after kidney transplantation: Long-term outcomes. Nephrol. Dial. Transplant. 2019, 34, 1240-1250. [CrossRef]

156. Baek, C.H.; Kim, H.; Yu, H.; Yang, W.S.; Han, D.J.; Park, S.K. Risk Factors of Acute Rejection in Patients with BK Nephropathy After Reduction of Immunosuppression. Ann. Transplant. 2018, 23, 704-712. [CrossRef] [PubMed]

157. Weist, B.J.; Wehler, P.; El Ahmad, L.; Schmueck-Henneresse, M.; Millward, J.M.; Nienen, M.; Neumann, A.U.; Reinke, P.; Babel, N. A revised strategy for monitoring BKV-specific cellular immunity in kidney transplant patients. Kidney Int. 2015, 88, 1293-1303. [CrossRef]

158. Schwarz, A.; Linnenweber-Held, S.; Heim, A.; Brocker, V.; Rieck, D.; Framke, T.; Raggub, L.; Haller, H. Factors influencing viral clearing and renal function during polyomavirus BK-associated nephropathy after renal transplantation. Transplantation 2012, 94, 396-402. [CrossRef] [PubMed]

159. Focosi, D.; Macera, L.; Pistello, M.; Maggi, F. Torque Teno virus viremia correlates with intensity of maintenance immunosuppression in adult orthotopic liver transplant. J. Infect. Dis. 2014, 210, 667-668. [CrossRef] [PubMed] 
160. De Vlaminck, I.; Khush, K.K.; Strehl, C.; Kohli, B.; Luikart, H.; Neff, N.F.; Okamoto, J.; Snyder, T.M.; Cornfield, D.N.; Nicolls, M.R.; et al. Temporal response of the human virome to immunosuppression and antiviral therapy. Cell 2013, 155, 1178-1187. [CrossRef] [PubMed]

161. Maggi, F.; Pistello, M.; Vatteroni, M.; Presciuttini, S.; Marchi, S.; Isola, P.; Fornai, C.; Fagnani, S.; Andreoli, E.; Antonelli, G.; et al. Dynamics of persistent TT virus infection, as determined in patients treated with alpha interferon for concomitant hepatitis $\mathrm{C}$ virus infection. J. Virol. 2001, 75, 11999-12004. [CrossRef]

162. Strassl, R.; Schiemann, M.; Doberer, K.; Gorzer, I.; Puchhammer-Stockl, E.; Eskandary, F.; Kikic, Z.; Gualdoni, G.A.; Vossen, M.G.; Rasoul-Rockenschaub, S.; et al. Quantification of Torque Teno Virus Viremia as a Prospective Biomarker for Infectious Disease in Kidney Allograft Recipients. J. Infect. Dis 2018, 218, 1191-1199. [CrossRef]

163. Borkosky, S.S.; Whitley, C.; Kopp-Schneider, A.; zur Hausen, H.; de Villiers, E.M. Epstein-Barr virus stimulates torque teno virus replication: A possible relationship to multiple sclerosis. PLoS ONE 2012, 7, e32160. [CrossRef]

164. Haloschan, M.; Bettesch, R.; Gorzer, I.; Weseslindtner, L.; Kundi, M.; Puchhammer-Stockl, E. TTV DNA plasma load and its association with age, gender, and HCMV IgG serostatus in healthy adults. Age 2014, 36, 9716. [CrossRef]

165. Focosi, D.; Maggi, F.; Albani, M.; Macera, L.; Ricci, V.; Gragnani, S.; Di Beo, S.; Ghimenti, M.; Antonelli, G.; Bendinelli, M.; et al. Torquetenovirus viremia kinetics after autologous stem cell transplantation are predictable and may serve as a surrogate marker of functional immune reconstitution. J. Clin. Virol. 2010, 47, 189-192. [CrossRef] [PubMed]

166. Rigante, D.; Mazzoni, M.B.; Esposito, S. The cryptic interplay between systemic lupus erythematosus and infections. Autoimmun Rev. 2014, 13, 96-102. [CrossRef]

167. Wootton, S.C.; Kim, D.S.; Kondoh, Y.; Chen, E.; Lee, J.S.; Song, J.W.; Huh, J.W.; Taniguchi, H.; Chiu, C.; Boushey, H.; et al. Viral infection in acute exacerbation of idiopathic pulmonary fibrosis. Am. J. Respir. Crit. Care Med. 2011, 183, 1698-1702. [CrossRef]

168. Schiemann, M.; Puchhammer-Stockl, E.; Eskandary, F.; Kohlbeck, P.; Rasoul-Rockenschaub, S.; Heilos, A.; Kozakowski, N.; Gorzer I.; Kikic, Z.; Herkner, H.; et al. Torque Teno Virus Load-Inverse Association With Antibody-Mediated Rejection After Kidney Transplantation. Transplantation 2017, 101, 360-367. [CrossRef]

169. Solis, M.; Velay, A.; Gantner, P.; Bausson, J.; Filipputtu, A.; Freitag, R.; Moulin, B.; Caillard, S.; Fafi-Kremer, S. Torquetenovirus viremia for early prediction of graft rejection after kidney transplantation. J. Infect. 2019, 79, 56-60. [CrossRef] [PubMed]

170. Fernandez-Ruiz, M.; Albert, E.; Gimenez, E.; Ruiz-Merlo, T.; Parra, P.; Lopez-Medrano, F.; San Juan, R.; Polanco, N.; Andres, A.; Navarro, D.; et al. Monitoring of alphatorquevirus DNA levels for the prediction of immunosuppression-related complications after kidney transplantation. Am. J. Transplant. 2019, 19, 1139-1149. [CrossRef] [PubMed]

171. Doberer, K.; Schiemann, M.; Strassl, R.; Haupenthal, F.; Dermuth, F.; Gorzer, I.; Eskandary, F.; Reindl-Schwaighofer, R.; Kikic, Z.; Puchhammer-Stockl, E.; et al. Torque teno virus for risk stratification of graft rejection and infection in kidney transplant recipients-A prospective observational trial. Am. J. Transplant. 2020, 20, 2081-2090. [CrossRef]

172. Handala, L.; Descamps, V.; Morel, V.; Castelain, S.; Francois, C.; Duverlie, G.; Helle, F.; Brochot, E. No correlation between Torque Teno virus viral load and BK virus replication after kidney transplantation. J. Clin. Virol. 2019, 116, 4-6. [CrossRef]

173. Ahlenstiel-Grunow, T.; Liu, X.; Schild, R.; Oh, J.; Taylan, C.; Weber, L.T.; Staude, H.; Verboom, M.; Schroder, C.; Sabau, R.; et al. Steering Transplant Immunosuppression by Measuring Virus-Specific T Cell Levels: The Randomized, Controlled IVIST Trial. J. Am. Soc. Nephrol. 2020, 32, 502-516.

174. Randhawa, P.S.; Schonder, K.; Shapiro, R.; Farasati, N.; Huang, Y. Polyomavirus BK neutralizing activity in human immunoglobulin preparations. Transplantation 2010, 89, 1462-1465. [CrossRef] [PubMed]

175. Randhawa, P.; Pastrana, D.V.; Zeng, G.; Huang, Y.; Shapiro, R.; Sood, P.; Puttarajappa, C.; Berger, M.; Hariharan, S.; Buck, C.B. Commercially available immunoglobulins contain virus neutralizing antibodies against all major genotypes of polyomavirus BK. Am. J. Transplant. 2015, 15, 1014-1020. [CrossRef]

176. Sener, A.; House, A.A.; Jevnikar, A.M.; Boudville, N.; McAlister, V.C.; Muirhead, N.; Rehman, F.; Luke, P.P. Intravenous immunoglobulin as a treatment for BK virus associated nephropathy: One-year follow-up of renal allograft recipients. Transplantation 2006, 81, 117-120. [CrossRef] [PubMed]

177. Gelfand, E.W. Intravenous immune globulin in autoimmune and inflammatory diseases. N. Engl. J. Med. 2012, 367, 2015-2025. [CrossRef] [PubMed]

178. Vu, D.; Shah, T.; Ansari, J.; Naraghi, R.; Min, D. Efficacy of intravenous immunoglobulin in the treatment of persistent BK viremia and BK virus nephropathy in renal transplant recipients. Transplant. Proc. 2015, 47, 394-398. [CrossRef]

179. Shah, T.; Vu, D.; Naraghi, R.; Campbell, A.; Min, D. Efficacy of Intravenous Immunoglobulin in the Treatment of Persistent BK Viremia and BK Virus Nephropathy in Renal Transplant Recipients. Clin. Transpl. 2014, 47, 109-116.

180. Matsumura, S.; Kato, T.; Taniguchi, A.; Kawamura, M.; Nakazawa, S.; Namba-Hamano, T.; Abe, T.; Nonomura, N.; Imamura, R. Clinical Efficacy of Intravenous Immunoglobulin for BK Polyomavirus-Associated Nephropathy After Living Kidney Transplantation. Ther. Clin. Risk Manag. 2020, 16, 947-952. [CrossRef]

181. Kable, K.; Davies, C.D.; O'Connell, P.J.; Chapman, J.R.; Nankivell, B.J. Clearance of BK Virus Nephropathy by Combination Antiviral Therapy With Intravenous Immunoglobulin. Transplant. Direct. 2017, 3, e142. [CrossRef] [PubMed]

182. Velay, A.; Solis, M.; Benotmane, I.; Gantner, P.; Soulier, E.; Moulin, B.; Caillard, S.; Fafi-Kremer, S. Intravenous Immunoglobulin Administration Significantly Increases BKPyV Genotype-Specific Neutralizing Antibody Titers in Kidney Transplant Recipients. Antimicrob. Agents Chemother. 2019, 63. [CrossRef] 
183. Miller, R.J.H.; Kwiecinski, J.; Shah, K.S.; Eisenberg, E.; Patel, J.; Kobashigawa, J.A.; Azarbal, B.; Tamarappoo, B.; Berman, D.S.; Slomka, P.J.; et al. Coronary computed tomography-angiography quantitative plaque analysis improves detection of early cardiac allograft vasculopathy: A pilot study. Am. J. Transplant. 2020, 20, 1375-1383. [CrossRef]

184. Wan, S.S.; Ying, T.D.; Wyburn, K.; Roberts, D.M.; Wyld, M.; Chadban, S.J. The Treatment of Antibody-Mediated Rejection in Kidney Transplantation: An Updated Systematic Review and Meta-Analysis. Transplantation 2018, 102, 557-568. [CrossRef] [PubMed]

185. Lefaucheur, C.; Nochy, D.; Andrade, J.; Verine, J.; Gautreau, C.; Charron, D.; Hill, G.S.; Glotz, D.; Suberbielle-Boissel, C. Comparison of combination Plasmapheresis/IVIg/anti-CD20 versus high-dose IVIg in the treatment of antibody-mediated rejection. Am. J. Transplant. 2009, 9, 1099-1107. [CrossRef] [PubMed]

186. Rovescalli, A.C.; Brunello, N.; Franzetti, C.; Racagni, G. Interaction of putative endogenous tryptolines with the hypothalamic serotonergic system and prolactin secretion in adult male rats. Neuroendocrinology 1986, 43, 603-610. [CrossRef]

187. Rao, Z.; Huang, Z.; Song, T.; Lin, T. A lesson from kidney transplantation among identical twins: Case report and literature review. Transpl. Immunol. 2015, 33, 27-29. [CrossRef] [PubMed]

188. Iturriza-Gomara, M.; O’Brien, S.J. Foodborne viral infections. Curr. Opin. Infect. Dis. 2016, 29, 495-501. [CrossRef] [PubMed]

189. Papadopoulou, A.; Gerdemann, U.; Katari, U.L.; Tzannou, I.; Liu, H.; Martinez, C.; Leung, K.; Carrum, G.; Gee, A.P.; Vera, J.F.; et al. Activity of broad-spectrum T cells as treatment for AdV, EBV, CMV, BKV, and HHV6 infections after HSCT. Sci. Transl. Med. 2014, 6, 242ra83. [CrossRef] [PubMed]

190. Nelson, A.S.; Heyenbruch, D.; Rubinstein, J.D.; Sabulski, A.; Jodele, S.; Thomas, S.; Lutzko, C.; Zhu, X.; Leemhuis, T.; Cancelas, J.A.; et al. Virus-specific T-cell therapy to treat BK polyomavirus infection in bone marrow and solid organ transplant recipients. Blood Adv. 2020, 4, 5745-5754.

191. Kaur, A.; Wilhelm, M.; Wilk, S.; Hirsch, H.H. BK polyomavirus-specific antibody and T-cell responses in kidney transplantation: Update. Curr. Opin. Infect. Dis. 2019, 32, 575-583. [CrossRef]

192. Teunissen, E.A.; de Raad, M.; Mastrobattista, E. Production and biomedical applications of virus-like particles derived from polyomaviruses. J. Control. Release 2013, 172, 305-321. [CrossRef] [PubMed]

193. Pastrana, D.V.; Ray, U.; Magaldi, T.G.; Schowalter, R.M.; Cuburu, N.; Buck, C.B. BK polyomavirus genotypes represent distinct serotypes with distinct entry tropism. J. Virol. 2013, 87, 10105-10113. [CrossRef] [PubMed]

194. Husseiny, M.I.; Lacey, S.F. Development of infectious recombinant BK virus. Virus Res. 2011, 161, 150-161. [CrossRef] [PubMed]

195. Kesherwani, V.; Tarang, S. An immunoinformatic approach to universal therapeutic vaccine design against BK virus. Vaccine 2019, 37, 3457-3463. [CrossRef] 